\title{
THE ORIGIN AND STRUCTURE OF THE LOWER CRUST OF OCEANS AND BACK-ARC SEAS: EVIDENCE FROM THE MARKOV DEEP (MID-ATLANTIC RIDGE) AND THE VOIKAR OPHIOLITE ASSOCIATION (POLAR URALS)
}

\section{E. V. Sharkov \\ Institute of Geology of Ore Deposits, Petrography, Mineralogy and Geochemistry of RAS, Moscow, Russia}

\begin{abstract}
The Markov Deep (the axial part of the slow-spreading Mid-Atlantic Ridge, $6^{\circ} \mathrm{N}$, Sierra Leone oceanic core complex) and the Paleozoic Voikar ophiolite association (Polar Urals) formed in the back-arc sea conditions. In both cases, the lower crust of a close structure was formed on the basements composed of depleted peridotites of the ancient lithospheric mantle. The available data show that the composition of the lower crust of the oceans and back-arc seas is dominated by layered mafic-ultramafic intrusions originating from the MORB melts, and suggest a similar asthenospheric source of magmas. Sills and dykes formed from other magma sources represent the second structural element of the lower oceanic crust: in case of the ocean, mainly ferrogabbroids originating from specific melts with the OIB involvement, and, in case of the back-sea sea, gabbro-norites of the supra-subduction calc-alkaline series. In both cases, the upper crust originates from basaltic flows that occurred later and are associated with new episodes in the tectonic development. According to [Sharkov, 2012], the development of slow-spreading ridges takes place in discrete impulses and non-simultaneously along their entire length. Furthermore, oceanic core complexes (OCC) in their axial parts are the ridge segments, where spreading is resumed. At the OCC stage, newly formed basalt melts move upwards from the magma generation zone into fractures (dykes) through the lithospheric mantle, and the thickness of the lower crust is built up by sills. As spreading develops in this area, the crust becomes thicker from below due to underplating in form of large layered intrusions. The newly formed restites, in their turn, cause an increase in the lithospheric mantle thickness from below. Apparently, the lower crust formed in the back-arc seas according to a similar scenario, although complicated by the processes taking place in the subduction zone.
\end{abstract}

Key words: slow-spreading ridge; oceanic core complex (OCC); lower crust; layered mafic-ultramafic intrusion; back-arc spreading; underplating

For citation: Sharkov E.V., 2019. The origin and structure of the lower crust of oceans and back-arc seas: evidence from the Markov Deep (Mid-Atlantic Ridge) and the Voikar ophiolite association (Polar Urals). Geodynamics \& Tectonophysics 10 (1), 101-121. doi:10.5800/GT2019-10-1-0406. 


\title{
ПРОИСХОЖДЕНИЕ И СТРОЕНИЕ НИЖНЕЙ КОРЫ ОКЕАНОВ И ЗАДУГОВЫХ МОРЕЙ: СВИДЕТЕЛЬСТВА ПО ВПАДИНЕ МАРКОВА (СРЕДИННО-АТЛАНТИЧЕСКИЙ ХРЕБЕТ) И ВОЙКАРСКОЙ ОФИОЛИТОВОЙ АССОЦИАЦИИ (ПОЛЯРНЫЙ УРАЛ)
}

\author{
E. В. Шарков
}

Институт геологии рудных месторождений, петрографии, минералогии и геохимии РАН, Москва, Россия

\begin{abstract}
Аннотация: На примере впадины Маркова (осевая часть медленно-спредингового Срединно-Атлантического хребта, $6^{\circ}$ с.ш., внутренний океанический комплекс Сьерра-Леоне) и палеозойской Войкарской офиолитовой ассоциации (Полярный Урал), формировавшейся в условиях задугового моря, показано, что в обоих случаях нижняя кора имеет сходное строение и формировалась на фундаменте, сложенном деплетированными перидотитами древней литосферной мантии. Согласно имеющимся данным, ведущую роль в составе нижней коры океанов и задуговых морей играют расслоенные мафит-ультрамафитовые интрузивы, произошедшие из расплавов типа MORB, что предполагает сходный астеносферный источник магм. Вторым элементом строения нижней океанической коры являются силлы и дайки, образовавшиеся за счет других источников магм. В случае океана они сложены преимущественно феррогабброидами, произошедшими за счет специфических расплавов с участием OIB, а в задуговом море - габбро-норитами надсубдукционной известково-щелочной серии. Верхняя кора в обоих случаях образована более поздними излияниями базальтов, связанными с новыми эпизодами развития этих тектонических структур. Как было показано ранее [Sharkov, 2012], развитие медленно-спрединговых хребтов происходит дискретными пульсами и не одновременно по всей их длине. При этом внутренние океанические комплексы (ВОК) в их осевых частях как раз и представляют собой сегменты хребта, где происходит возобновление спрединга. На стадии формирования ВОК новообразованный базальтовый расплав поднимается из зоны генерации магм по трещинам (дайкам) сквозь литосферную мантию и наращивает существующую нижнюю кору в форме силлов, а по мере развития на данном участке зоны спрединга - снизу, путем андерплейтинга в форме крупных расслоенных интрузивов; новообразованные реститы, в свою очередь, наращивают снизу литосферную мантию. Образование нижней коры в задуговых морях, по-видимому, происходило по сходному сценарию, но осложнялось процессами в зоне субдукции.
\end{abstract}

Ключевые слова: медленно-спрединговый хребет; внутренний океанический комплекс; нижняя кора; расслоенный мафит-ультрамафитовый интрузив; задуговый спрединг; андерплейтинг

\section{1. ВВЕДЕНИЕ}

Существует консенсус, что нижняя океаническая кора сложена преимущественно различными габброидами при подчиненной роли ультрамафитов, что предполагает наличие между мантией и верхней океанической корой затвердевших промежуточных очагов базальтовой магмы (интрузивов). Вместе с тем в настоящее время остается неясным, как именно образовалась эта кора. Согласно [Pearce, 2002; Searle, 2013, и ссылки в этих работах], сейчас преобладают две точки зрения на происхождение нижней коры океанов: 1) при затвердевании крупной линзы базальтового расплава с последующим растеканием «каши» кристаллов от оси хребта (модель «габбрового ледника» («gabbro glacier»: [Quick, Denlinger, 1993]); 2) путем внедрения многочисленных базитовых силлов.
Близкая по составу мафит-ультрамафитовая нижняя кора развивается и в задуговых морях, в другой тектонической обстановке, не связанной напрямую с процессом океанического спрединга. Вопрос о происхождении этой коры и ее сходстве и различии с нижней корой современного океана пока остается открытым.

Целью настоящей работы было выявление главных черт сходства и различия в строении нижней коры океанов и задуговых морей, а также обсуждение механизмов ее формирования и развития. Чтобы не углубляться в детали, было решено провести обсуждение на двух хорошо изученных примерах, что позволило не отвлекаться на второстепенные особенности строения подобных комплексов. В качестве таких примеров были выбраны объекты, в изучении которых автор принимал непосредственное участие: 1) один из сегментов осевой части со- 
временного медленно-спредингового Срединно-Атлантического хребта (САХ) (глубоководная впадина Маркова в Центральной Атлантике); 2) нижнекоровый габбровый комплекс хорошо сохранившейся палеозойской Войкарской офиолитовой ассоциации на Полярном Урале, которая формировалась в условиях задугового моря [Knipper et al., 2001; Estrada et al., 2012].

\section{2. СТРОЕНИЕ НИЖНЕЙ КОРЫ СРЕДИННО- АТЛАНТИЧЕСКОГО ХРЕБТА (НА ПРИМЕРЕ ВПАДИНЫ МАРКОВА)}

Нижняя кора современных океанов выходит на поверхность их дна в пределах так называемых внутренних океанических комплексов (ВОК), известных в англоязычной литературе как осеапic core complexes (OCC). Эти комплексы представляют собой вытянутые куполообразные подъемы тектонизированной гетерогенной океанической литосферы длиной в десятки - первые сотни километров в осевых частях медленно-спрединговых хребтов типа Срединно-Атлантического (САХ) и ЮгоЗападно-Индийского (ЮЗИХ) [Tucholke, 1998; Escartin et al., 2008; MacLeod et al., 2009; Conference..., 2010; Silantyev, 1998; Searle, 2013; Ciazela et al., 2015, u ссылки в этих работах]. ВОКи характеризуются обширными выходами на дне океана измененных габброидов нижней коры и серпентинизированных перидотитов мантии, а часто также наличием крупных гидротермальных полей с богатой рудной минерализацией. Считается, что они возникают в процессе океанического спрединга в периоды пониженной магматической активности или ее отсутствия («сухой спрединг»), хотя этому имеется и другое объяснение (см. Обсуждение).

Во всех ВОКах разрез океанической литосферы в целом выглядит аналогично: в его основании обычно развиты сильно серпентинизированные мантийные перидотиты, выше расположены измененные габброиды и ультрамафиты нижней коры, мощность которой обычно составляет 3-4 км [Searle, 2013].

Потоки свежих базальтов верхней коры несогласно перекрывают сильно деформированные и метаморфизованные плутонические породы. Это важное обстоятельство, на которое обычно не обращают внимание, свидетельствует о существовании значительных перерывов в развитии зон океанического спрединга, по крайней мере в медленноспрединговых хребтах.

Одним из таких внутренних океанических комплексов является ВОК Сьерра-Леоне в экваториальной части CAX [Pushcharovsky et al., 2004; Bortnikov, Sharkov, 2011; u дp.]. Здесь в осевой части хребта (зоне спрединга) наблюдается система кулисооб- разно расположенных грабенообразных впадин. Наиболее глубокой из них (до 5 км от поверхности океана) является впадина Маркова (550'-602' с.ш.) длиной около 20 км (рис. 1), где на поверхность дна выведены сильно измененные глубинные (плутонические) породы (габброиды нижней коры и перидотиты мантии). Автор принимал участие в работах по драгированию дна на этом участке, производившихся в 10-м рейсе НИС «Академик Иоффе» (2001-2002 гг.) и 22-м рейсе НИС «Профессор Логачев» (2003 г.).

О строении литосферы ВОК можно судить по результатам дистанционных исследований восточного борта впадины Маркова, выполненных в 22-м рейсе НИС «Профессор Логачев» с помощью морского акустического комплекса (сонара бокового обзора) ГБО МАК-1М (рис. 2). Кора здесь имеет хорошо выраженную субгоризонтальную расслоенную структуру, частично маскируемую осадками, которая сильно напоминает строение расслоенных мафит-ультрамафитовых интрузивов на континентах. Хорошо видны многочисленные крутопадающие разломы, один из которых (в левой части снимка) заполнен дайкой долерита, по-видимому, представляющей собой подводящий канал лавового потока. В нижней правой части изображения видно, как расслоенность «задирается» разломом, приобретая крутое залегание.

Спектр драгированных во впадине Маркова пород описан во многих публикациях [Pushcharovsky et al., 2004; Sharkov et al., 2005, 2007, 2008; Savel'eva et $a l ., 2006 ;$ u $\partial p$.] и весьма обычен для ВОК медленноспрединговых хребтов. Здесь развиты:

1. Катаклазированные серпентинизированные ультрабазиты (преимущественно гарцбургиты, реже дуниты и лерцолиты), в основном мантийные реститы, а также кумулаты (некоторые дуниты) [Savel'eva et al., 2006]. Было драгировано несколько образцов, в которых ультрабазиты не подверглись серпентинизации, сохранились их структуры и минеральный состав (рис. 3).

2. В разной степени измененные габброиды, слагающие основной объем драгированного материала, представлены здесь, как и в других ВОК, двумя главными разновидностями. Среди них преобладают так называемые «примитивные» (высоко-Mg) габброиды: троктолиты (рис. 4), оливиновые габбpo, габбро и лейкогаббро [Sharkov et al., 2005]. Такие магнезиальные габброиды широко развиты в породах нижней коры современных океанов и традиционно рассматриваются как интрузивные аналоги MORB [Dick et al., 2008; Searle, 2013; и дp.], с чем согласуется и состав наблюдаемых в них расплавных включений [Simonov et al., 2009].

3. Вторая разновидность габброидов образована как измененными, так и свежими феррогабброи- 
(a)

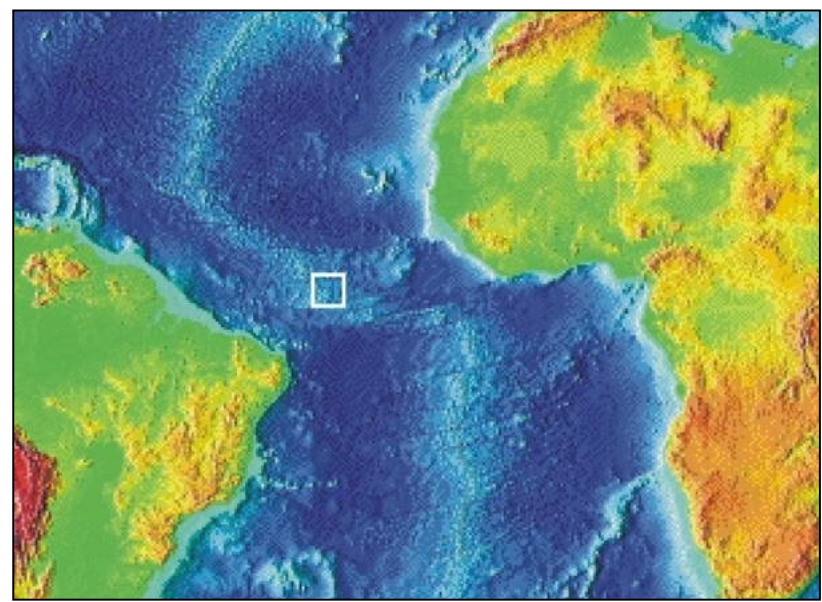

(б)

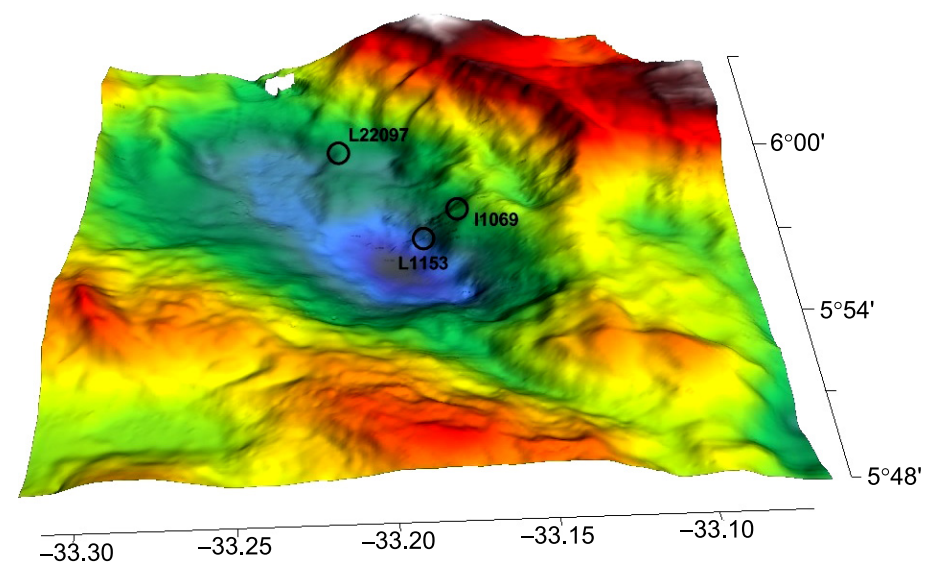

Рис. 1. Местоположение полигона Сьерра-Леоне $(a)$ и схема строения впадины Маркова по С.Г. Сколотневу и др. [Skolotnev et al., 2010] (б).

IFig. 1. Location of the Sierra Leone polygon (a) and structure of the Markov Deep (after [Skolotnev et al., 2010] (б).

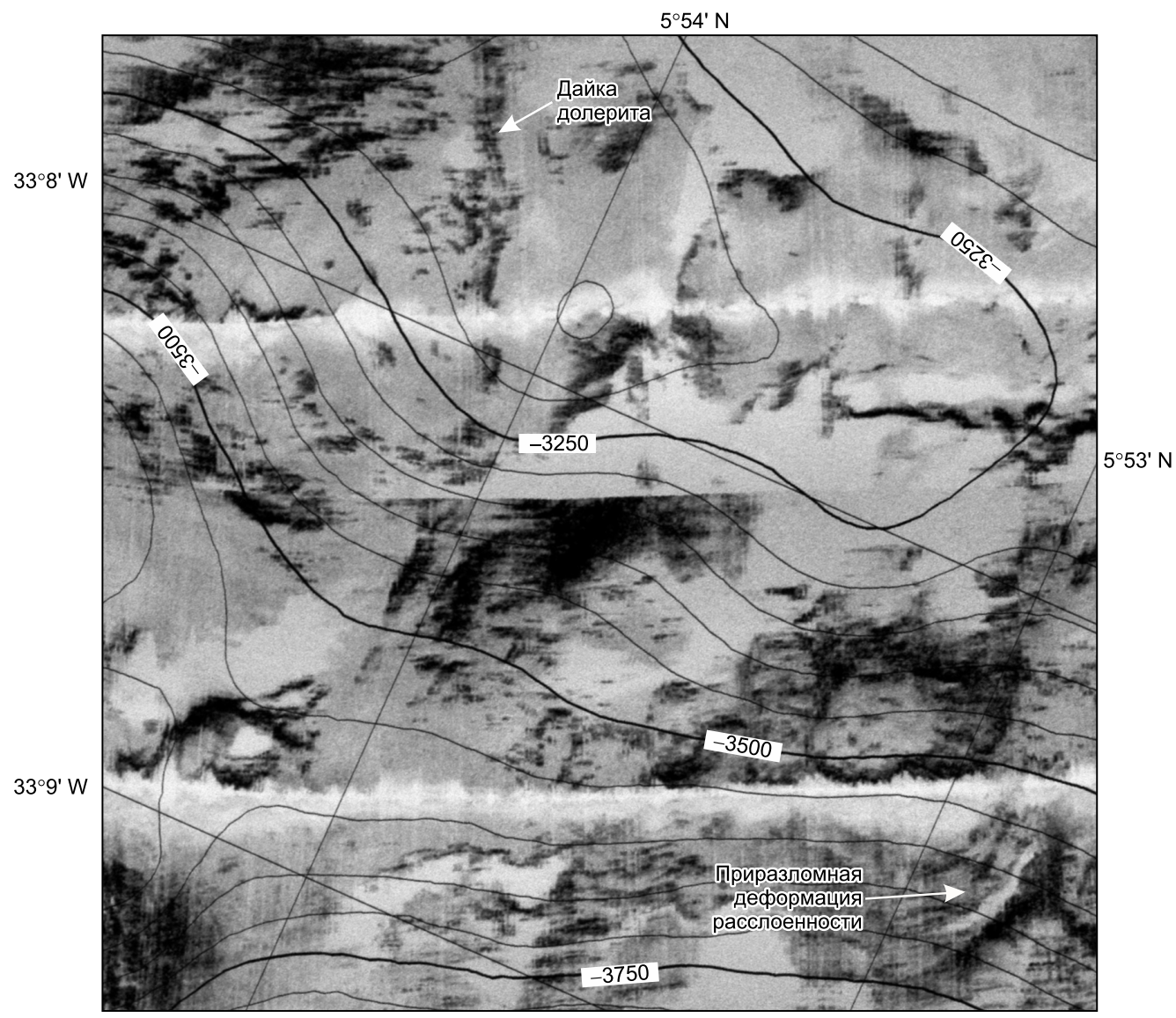

Рис. 2. Изображение средней части разреза коры в восточном борту впадины Маркова. Получено с помощью морского акустического комплекса (сонара бокового обзора) ГБО МАК-1М в 22-м рейсе НИС «Профессор Логачев». Хорошо видна расслоенная структура литосферы, частично перекрытая осадками (светло-серое), а также многочисленные крутопадающие разломы. Один из них заполнен дайкой долерита (на левой стороне изображения) вероятного подводящего канала базальтового потока в верхней коре.

Fig. 2. The middle part of the crust cross-section for the eastern slope of the Markov Deep. The image was taken by a sideview sonar GBO MAK-1M in the 22nd voyage of RV Professor Logatchev. The stratified structure of the lithosphere, which is partially covered by sediments (light gray), as well as numerous steeply dipping faults are clearly visible. One of the faults is filled with a dolerite dyke (on the left side of the image) of a probable basalt supply channel in the upper crust. 


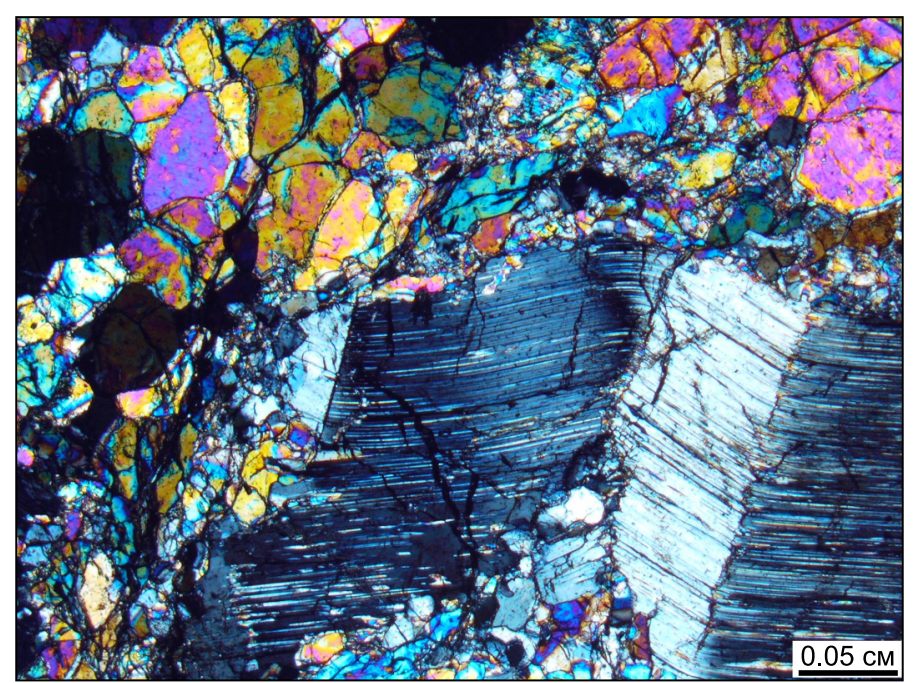

Рис. 3. Микрофото катакластической структуры в деформированном гарцбургите (рестите); на первом плане - порфирокласт ортопироксена среди гранулированного оливина. Коллекция Е.В. Шаркова, шлиф І1063-29, николи +.

Fig. 3. Microphotographs of a cataclastic structure in deformed harzburgite (restite); front - orthopyroxene porphyroclast among granulated olivine. Collection of E.V. Sharkov. Thin section I 1063-29, nikoli +.

дами, формирующими дайки и силлы в «примитивных» габбро, а также более крупные расслоенные тела с хорошо выраженной кумулятивной структурой. Феррогабброиды представлены серией пород от меланократовых троктолитов с Fe-Ti оксидами и коричневой роговой обманкой (паргаситом) до преобладающих роговообманковых (с паргаситом) Fe-Ti-оксидных оливиновых и безоливиновых габбро-норитов (рис. 5), норитов и, реже, габбро-диоритов. Содержания Fe-Ti оксидов (преимущественно ильменита, магнетит и титаномагнетит редки) варьируются от 3-5 до 10 об. \% [Sharkov et al., 2005].

Феррогабброиды, аналогичные встреченным на полигоне Сьерра-Леоне, весьма типичны для медленно-спрединговых хребтов, особенно САХ и ЮЗИХ, где часто развиты в форме даек и силлов в примитивных габбро [Thy, 2003]. Их происхождение весьма дискуссионно. Обычно они считаются продуктами кристаллизационной дифференциации MORB [Dick et al., 1992; Thy, 2003; и dp.]. Вместе с тем по своим геохимическим особенностям (см. ниже) и составу расплавных включений [Simonov et al., 1999, 2009] они близки к базальтам океанических островов (OIB), связанным с подъемом мантийных плюмов, а наличие интрузивных соотношений феррогабброидов с «примитивными» габбро скорее свидетельствует о их самостоятельном происхождении. Мы ранее выделили эти породы в качестве кремнеземистой Fe-Ti-оксидной серии, формировавшейся в ре- зультате ассимиляции магмами ОIB более древних гидратированных габброидов океанической коры [Sharkov et al., 2005, 2008].

4. Жилы и мелкие тела плагиогранитов (трондьемитов) (рис. 6), произошедшие при анатектическом плавлении пород гидратированной нижней коры в экзоконтактовых зонах свежих интрузивов габброидов [Aranovich et al., 2010].

5. Дайки и силлы долеритов среди примитивных габбро, довольно свежие, одна часть из которых близка к толеитовым базальтам, а другая - к феррогабброидам.

6. Базальты, в основном свежие, с корками закалочного вулканического стекла (рис. 7), потоки которых несогласно перекрывают измененные плутонические породы. По химизму они отвечают Е- и T-MORB (океанические платобазальты). Судя по магнезиальности лав и составу фенокристов, базальты не являются первичными мантийными выплавками, а претерпели кристаллизационную дифференциацию в промежуточных очагах и были частично контаминированы веществом габброидов [Sharkov et al., 2005, 2008].

Глубинные (плутонические) породы в большинстве случаев неравномерно подверглись вторичным преобразованиям. Согласно петрографическим данным, в этих породах, как габброидах, так и перидотитах (см. рис. 3), часто наблюдаются следы раннего высокотемпературного катаклаза, сопровождаемые появлением деформационных структур в магматических минералах (оливине, пироксене и

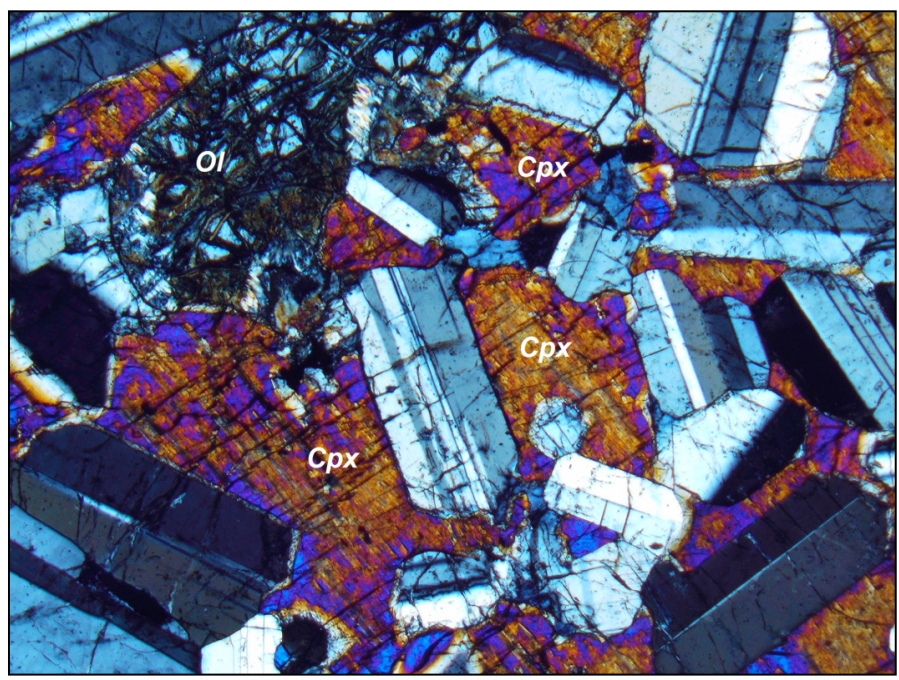

Рис. 4. Кумулятивная структура в троктолите (кумулус: $\mathrm{Ol}+\mathrm{Pl}, \mathrm{Cpx}$ в интерстициях). Коллекция Е.В. Шаркова. Шлиф I1069-16, николи+.

Fig. 4. Cumulative structure in troctolite (cumulus: $\mathrm{Ol}+\mathrm{Pl}$, Cpx in interstitia). Collection of E.V. Sharkov. Thin section I 1069-16, nicols+. 


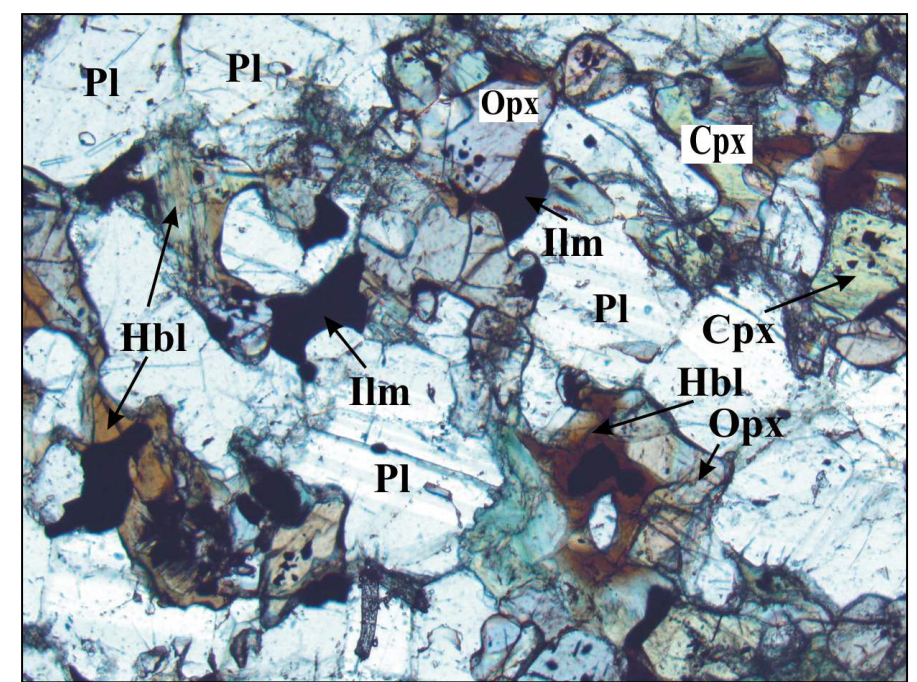

Рис. 5. Fе-Ті-оксидный роговообманковый габбронорит. Коллекция Е.В. Шаркова, шл. I1040-14, без анализатора.

Fig. 5. Fe-Ti-oxide hornblende gabbro-norite. Collection of E.V. Sharkov. Thin section I 1040-14, without analyzer.

плагиоклазе). Образование таких высокотемпературных катаклазитов связывается с пластическим течением уже затвердевших, но еще горячих пород
[Sharkov et al., 2005; Savel'eva et al., 2006]. Широко проявлены также хрупкопластичные и хрупкие деформации, сопровождаемые уже низкотемпературными изменениями пород, происходившими в условиях преимущественно зеленосланцевой фации метаморфизма. Перидотиты при этом обычно сильно, а часто и нацело серпентинизируются, габброиды амфиболизируются с замещением пироксенов и паргасита волокнистым актинолитом, а плагиоклаза соссюритом.

\section{3. ГЕОХИМИЧЕСКИЕ ОСОБЕННОСТИ ГЛАВНЫХ РАЗНОВИДНОСТЕЙ ПОРОД}

Геохимические особенности главных разновидностей пород нижней океанической коры отражены на рис. 7, составленном на основе результатов химических анализов, приведенных в работах [Sharkov et al., 2005, 2008]. Практически все габброиды полигона Сьерра-Леоне обогащены относительно N-MORB Pb, Ba и Ga и обеднены Zr, Th и Hf. Минимальные содержания РЗЭ и других несовместимых элементов наблюдаются в «примитивных» (высоко-Mg) троктолитах, оливиновых габбро, габбро и лейкогаббро, что обычно для расплавов типа MORB. Феррогабброиды, наоборот, характеризуют-
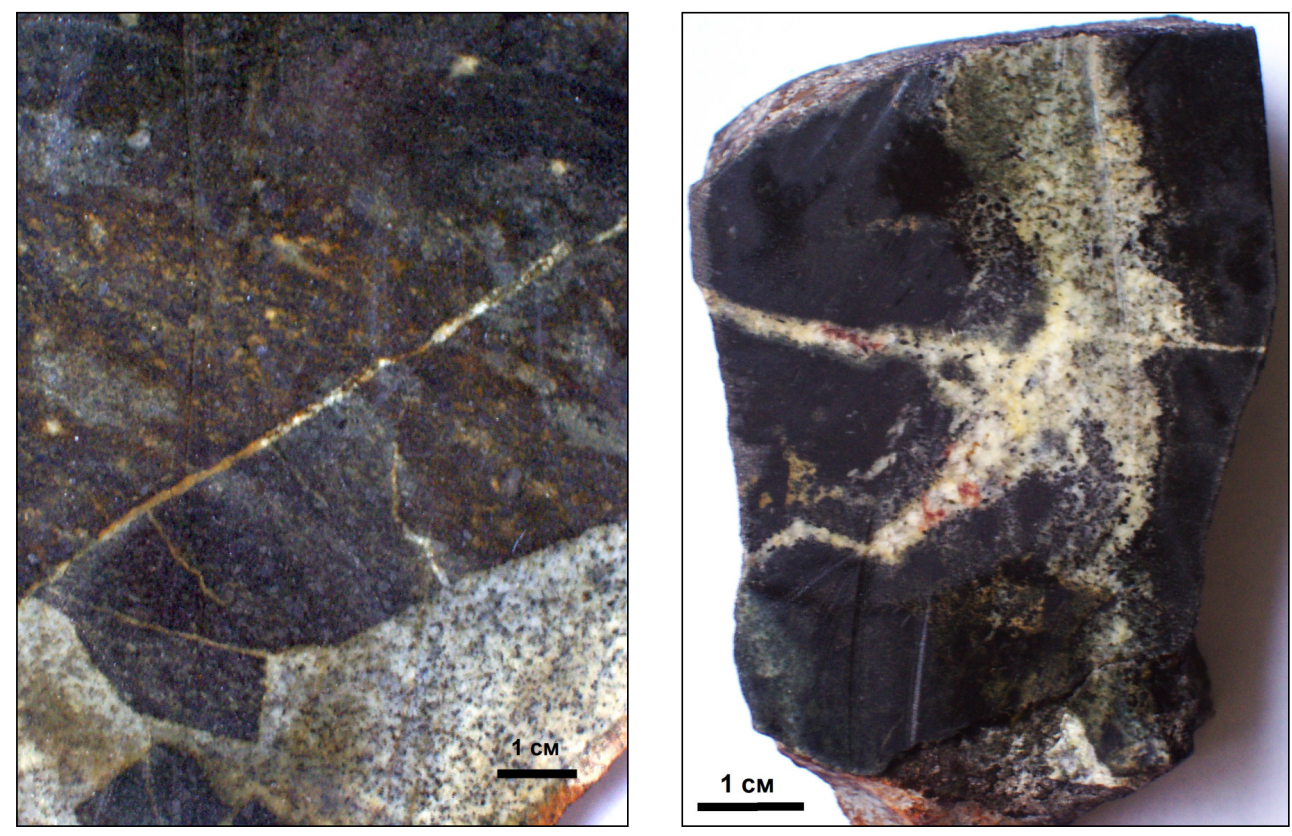

Рис. 6. Жилы плагиогранитов в экзоконтактах (зонах ороговикования) свежих габбровых интрузивов. Справа начальная стадия плавления протолита (вмещающего ороговикованное метагаббро), развивается вдоль трещин в протолите; слева - перемещенный гранитный расплав. Коллекция Е.В. Шаркова. Обр. I1060-29 и I1060-30 соответственно.

Fig. 6. Plagiogranite veins in exocontacts (hornfelsed zones) of the newly formed gabbro intrusive rocks. Right - initial stage of protolith melting (enclosing hornfelsed metagabbro), developed along fractures in the protolith; left - shifted granite melt. Collection of E.V. Sharkov. Samples I 1060-29 and I 1060-30, respectively. 
(a)
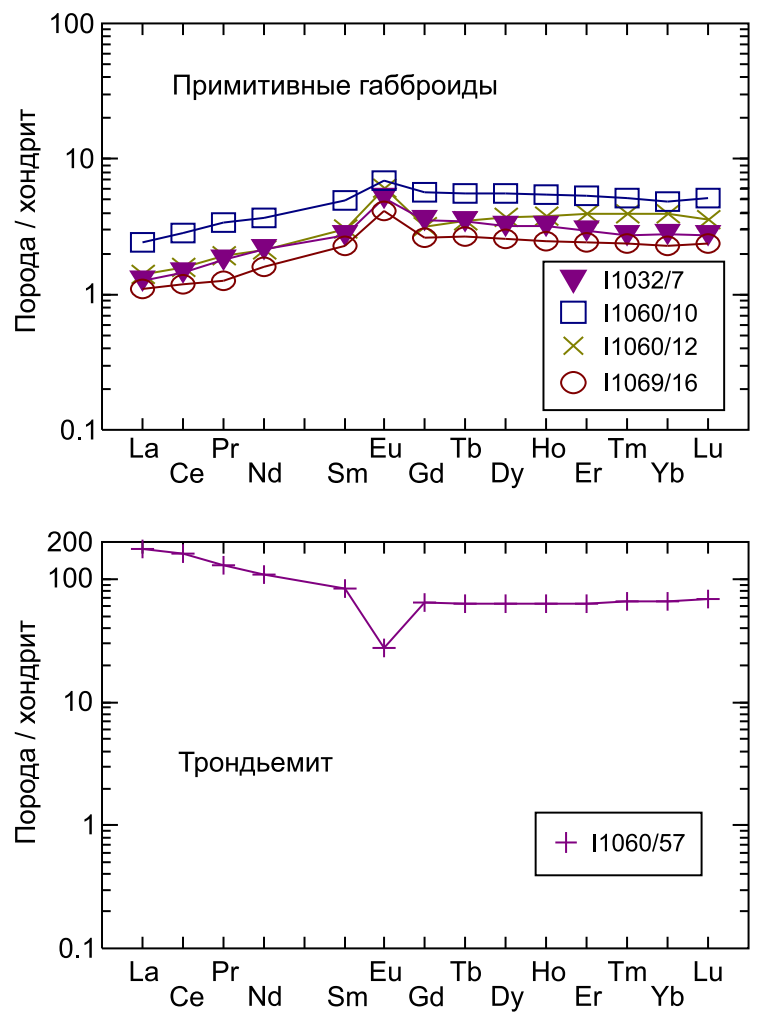

(б)
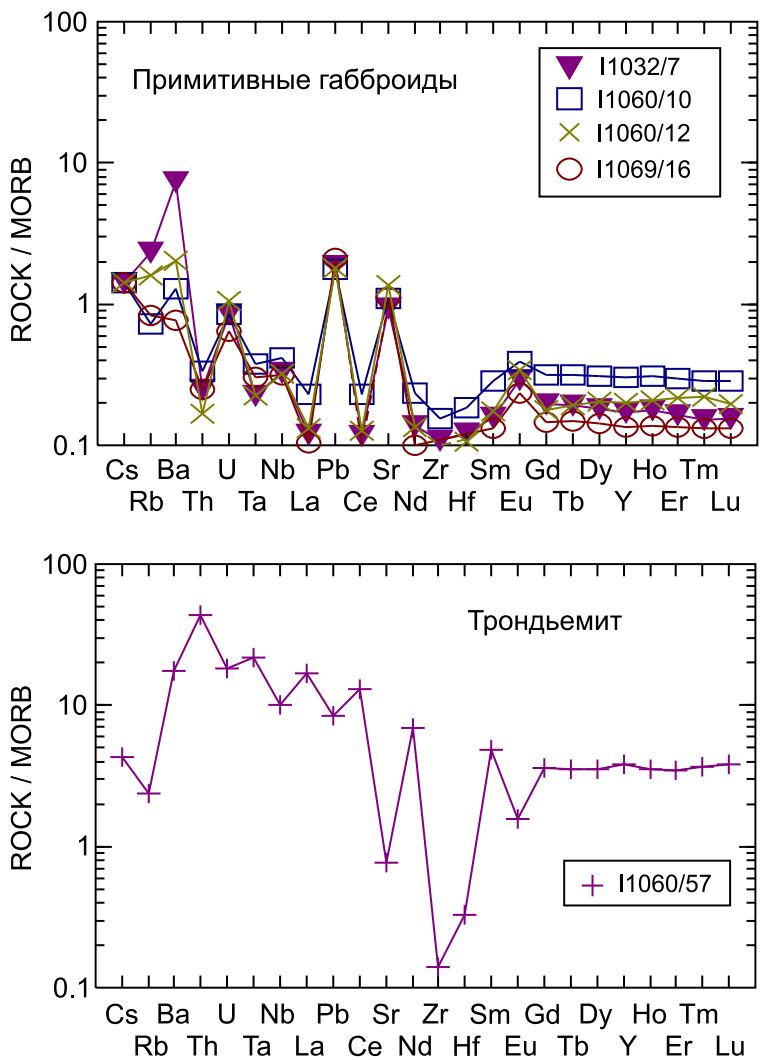
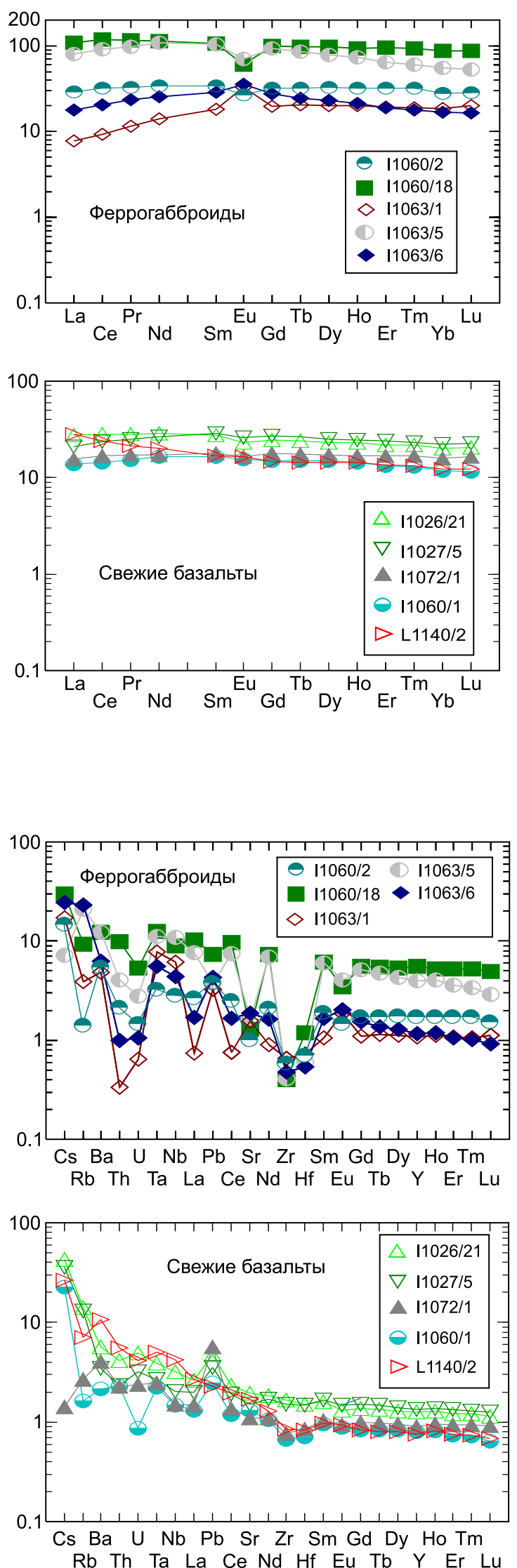

Рис. 7. Распределение РЗЭ в главных типах пород океанической коры во впадине Маркова (a) и спайдерграммы, иллюстрирующие распределение редких и редкоземельных элементов в главных типах пород впадины Маркова (б).

Fig. 7. REE distribution in oceanic crust rocks of the main types in the Markov Deep (a); and spider diagrams illustrating the distribution of rare and rare-earth elements in the rocks of the main types in the Markov Deep (б). 
ся относительно высокими содержаниями несовместимых элементов, в том числе $\mathrm{Cs}, \mathrm{Nb}$ и Та, а также РЗЭ, что характерно для магм типа ОIB.

Плагиограниты имеют свои собственные геохимические особенности, не связанные с процессами кристаллизационной дифференциации.

Свежие базальты сильно варьируются по содержанию $\mathrm{Cs}, \mathrm{Rb}$ и Ва и характеризуются положительной $\mathrm{Pb}$ аномалией. По составу они отвечают Е- и T-MORB (обогащенные и промежуточные океанические базальты), реже N-MORB.

Дуниты, троктолиты и габбро - типичные дифференциаты расслоенных мафит-ультрамафитовых интрузивов, произошедших из толеитовых расплавов, в данном случае - MORB, тогда как роговообманковые Fe-Ti-оксидные габбро-нориты образовались за счет расплавов кремнеземистой FeТі-оксидной серии. Нередко в образцах сохраняются элементы первичной расслоенности, включая кумулятивные структуры. Все это позволяет думать, что основной объем нижней коры ВОК Сьерра-Леоне сложен породами расслоенных мафитультрамафитовых интрузивов этих двух типов. Они являлись промежуточными очагами магматических систем, в которых накапливались расплавы, поступавшие из областей генерации магм, происходили процессы кристаллизационной дифференциации и смешения магм, а также процессы ассимиляции вмещающих габброидов нижней коры.

Преобладание среди габброидов сильно измененных разновидностей пород свидетельствует о их связи с предыдущим эпизодом (эпизодами?) тектономагматического развития океанической коры полигона. В результате подъема хребта они были выведены на поверхность дна и затем перекрыты потоками свежих базальтов. Находки свежих разновидностей пород среди них, возможно, связаны с современным эпизодом магматической активности.

Как уже указывалось, потоки свежих базальтов несогласно перекрывают деформированные и метаморфизованные плутонические породы (габброиды и перидотиты) и генетически с ними никак не связаны. Иными словами, здесь, в осевой части хребта, в зоне спрединга, по геологическим данным устанавливается два разновозрастных комплекса пород: (1) измененные породы «старой» океанической литосферы, в основном представленные образованиями предыдущего эпизода (эпизодов?) развития зоны спрединга, и (2) свежие базальты и долериты современного эпизода активности, с которыми, возможно, связаны некоторые дайки и силлы свежих феррогабброидов.

Таким образом, в бортах впадины Маркова вскрыт весь разрез океанической коры - от мантийных ультрабазитов через габбровый комплекс (нижняя кора) до свежих базальтов верхней коры, перекрывающих выходы более древних измененных плутонических пород. Имеющихся данных, конечно, недостаточно, чтобы построить здесь систематический разрез нижней коры, поскольку неизвестны ни распространенность разных типов пород, ни их положение в ее 3.5-километровом разрезе. Однако общая картина в целом соответствует данным по нижней коре других ВОК медленно-спрединговых хребтов [Searle, 2013]. Это позволяет думать о том, что, как и следовало ожидать, нижняя кора таких хребтов, произошедшая в аналогичных условиях, имеет относительно одинаковое строение и состав на всем их протяжении.

\section{4. ВОЙКАРСКИЙ ГАББРОВЫЙ КОМПЛЕКС (ПОЛЯРНЫЙ УРАЛ)}

В качестве примера строения нижней коры задугового моря рассмотрим нижнекоровый габбровый комплекс хорошо сохранившейся Войкарской (Войкаро-Сыньинской) офиолитовой ассоциации на Полярном Урале [Savelyeva, 1987; Knipper et al., 2001; Sharkov et al., 2001; Estrada et al., 2012; u $\partial p$.]. Согласно изотопно-геохронологическим данным (U-Pb метод по циркону), этот комплекс формировался на протяжении 65 млн лет: с 490 по 425 млн лет назад, с ордовика по силур [Queiroga et al., 2016].

Однако, по мнению С.А. Куренкова и его коллег [Kurenkov et al., 2002], находки бонинитов в составе этой ассоциации скорее свидетельствуют о ее первоначально-океаническом происхождении при последующем участии субдукционного магматизма, поскольку бониниты считаются индикаторами надсубдукционного магматизма примитивных энсиматических островных дуг типа Изу-Бонинской, Марианскй и др. [Crawford et al., 1989]. Однако в тылу этих вулканических дуг расположено Филиппинское море, так что в любом случае речь идет о задуговом спрединге. В отличии от большинства задуговых морей, здесь отсутствуют реликты древней континентальной коры, что, по-видимому, свидетельствует о высокой степени эволюции коры этого моря (см. раздел «Обсуждение»).

Так же как и в САХ, практически все плутонические породы войкарских офиолитов подверглись катаклазу и метаморфизму, поэтому кумулятивные структуры в них сохраняются редко, хотя общий облик пород свидетельствует о их интрузивном происхождении. Как и в САХ, катаклаз начинался с вязкопластичного течения пород при высоких температурах, которое по мере охлаждения сменялось хрупкопластичными и хрупкими деформациями в условиях преимущественно зеленосланцевой 
фации метаморфизма, приводя к сильной серпентинизации ультрамафитов и амфиболизации («уралитизации») мафитов.

Здесь также наблюдается большое количество разрывных нарушений разной ориентировки. Масштабы их невелики, так как разрез габбрового комплекса (т.е. нижней океанической коры) имеет в целом систематический характер, где смена пород (кумулатов) по вертикали согласуется с закономерностями кристаллизационной дифференциации при кристаллизации базальтовых (толеитовых) магм.

Этот комплекс залегает непосредственно на мантийных перидотитах. В наиболее сохранившихся участках последние представлены тонкорасслоенными и сильно деформированными (вплоть до изоклинальных складок) гарцбургитами и лерцолитами с многочисленными жилами дунитов, бронзититов и вебстеритов - предполагаемых путей миграции расплавов и флюидов [Savelieva et al., 2008].

Подобные складчатые деформации отсутствуют в породах вышележащего габбрового комплекса, залегающего непосредственно на мантийных ультрамафитах; граница между этими комплексами описывается как «петрографическое Мохо». Как видно из рис. 8, габбровый комплекс образован двумя мегаритмами, имеющими сложное строение. Нижний мегаритм начинается с мощного (около 500 м) горизонта однородных «краевых» дунитов (оливин-хромитовых кумулатов). Затем идет ритмичное переслаивание дунитов, верлитов и клинопироксенитов; в верхней части зоны переслаивания появляются прослои габбро, и завершает разрез мегаритма мощный (около 600 м) горизонт массивных габбро. Разрез этого мегаритма в целом близок по строению к разрезу крупных расслоенных интрузивов континентов, произошедших из толеитовых расплавов, таких как Скергаардский, Йоко-Довыренский и др. [Wager, Brown, 1968; Sharkov, 2006; u $\partial p$.].

Переходная зона образована переслаиванием дунитов, верлитов, габбро и троктолитов общей мощностью около 500 м. Важной особенностью пород Нижнего мегаритма и Промежуточной зоны является отсутствие в них ортопироксена.

Разрез Верхнего мегаритма в целом близок к разрезу Нижнего. Однако здесь породы секутся многочисленными жилами, силлами и расслоенными интрузивами оливиновых и безоливиновых габбро-норитов. В отличие от Fe-Тi-оксидных роговообманковых габбро-норитов САХ, габбро-нориты Верхнего мегаритма практически не содержат таких оксидов, особенно ильменита, что характерно для пород надсубдукционной известково-щелочной серии [Wilson, 1989]. Их внедрение было связа- но с самостоятельным эпизодом магматической активности. Таким образом, в пределах нижней коры Войкарского комплекса наблюдается совмещение продуктов кристаллизации магм как спредингового (толеитов типа MORB), так и супрасубдукционного происхождения, что было отмечено и в работе [Estrada et al., 2012]. Геохимические особенности типичных разновидностей пород охарактеризованы на рис. 9, составленном с использованием данных этих исследователей.

В целом, по вещественному составу, особенно по присутствию габбро-норитов известково-щелочного типа среди габброидов и ультрамафитов, связанных с кристаллизацией толеитовых магм, породы Войкарского габбрового комплекса близки к породам, драгированным со дна современного Филиппинского задугового моря [Laz'ko, Gladkov, 1991; Ohara et al., 2001].

Отсутствие в Нижнем мегаритме жил и силлов габбро-норитов может свидетельствовать о том, что он образовался позже Верхнего мегаритма. Поскольку образования габбрового комплекса контактируют непосредственно с мантийными породами, есть все основания думать, что этот мегаритм образовался путем внедрения и накопления базальтового расплава между мантией и корой, представленной в данном случае породами Верхнего мегаритма, уже интрудированными к тому времени телами габбро-норитов. Иными словами, здесь имел место андерплейтинг в понимании [Rudnick, 1990], который был представлен внедрением вдоль границы кора-мантия крупного расслоенного мафит-ультрамафитового интрузива, близкого по составу к интрузивам, слагающим нижнюю кору во впадине Маркова, САХ. Этому андерплейтингу, по-видимому, предшествовало формирование Переходной зоны, в которой габбронориты также отсутствуют и которая, скорее всего, представляла собой самостоятельный эпизод формирования нижней коры.

Крутопадающие дайки долеритов секут породы как габбрового, так и мантийного комплекса. Как и в случае впадины Маркова, они, по-видимому, являлись подводящими каналами вулканитов верхней коры. Иными словами, здесь фиксируются по крайней мере три, а возможно, и четыре самостоятельных эпизода интрузивного магматизма.

Таким образом, судя по геологическим данным, формирование габбрового комплекса Войкарской офиолитовой ассоциации началось с образования Верхнего мегаритма, содержащего жилы, дайки, пластовые тела и крупные расслоенные интрузивы габбро-норитов, произошедших за счет расплавов надсубдукционной известково-щелочной серии. При этом основной объем коры во всем разрезе образован дунитами, верлитами, клинопироксенита- 
E.V. Sharkov: The origin and structure of the lower crust of oceans and back-arc seas...

M

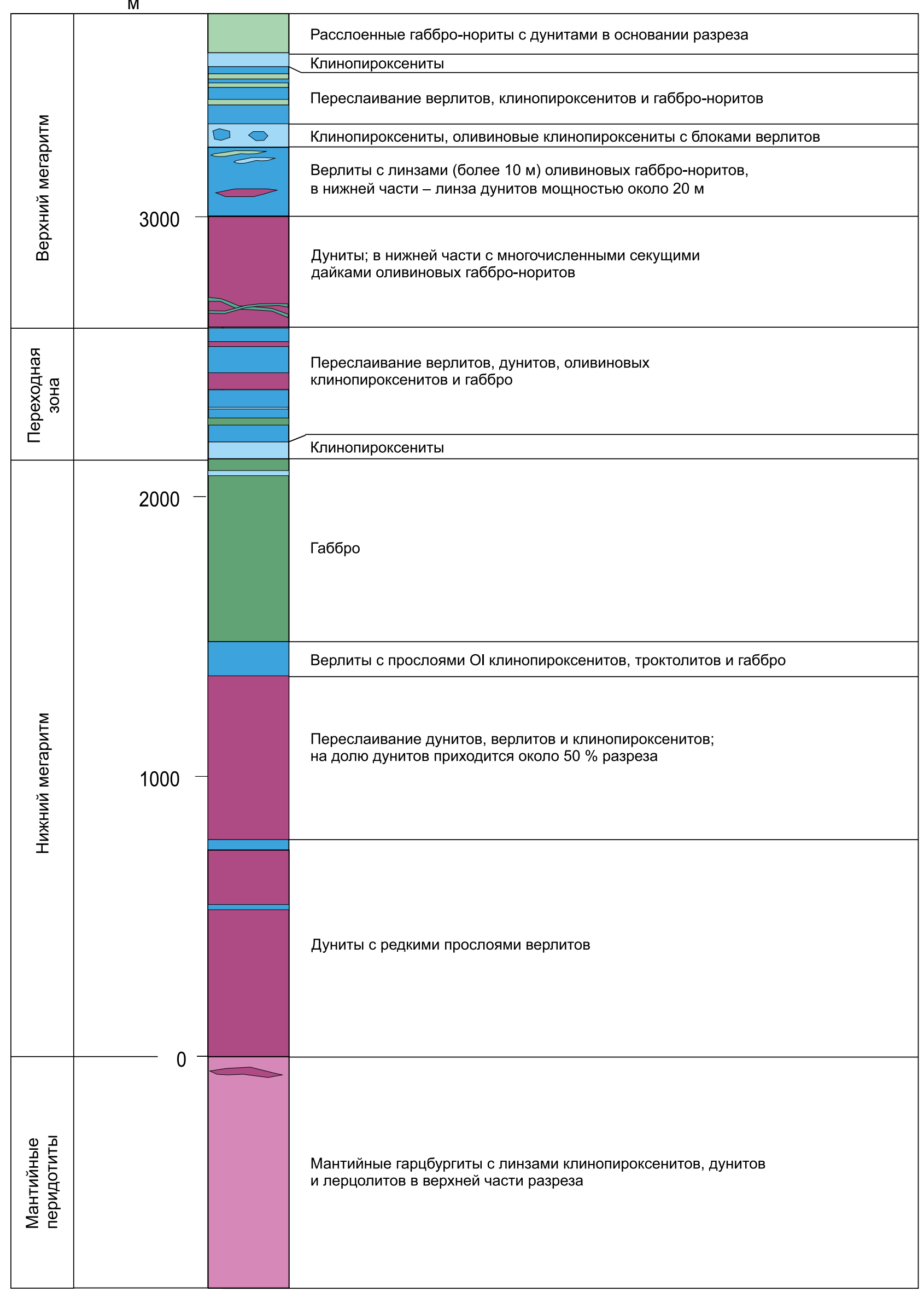

| Рис. 8. Разрез Войкарского габбрового комплекса (по [Sharkov et al., 2001], с уточнениями).

I Fig. 8. Cross-section of the Voikar gabbro complex (modified after [Sharkov et al., 2001]). 

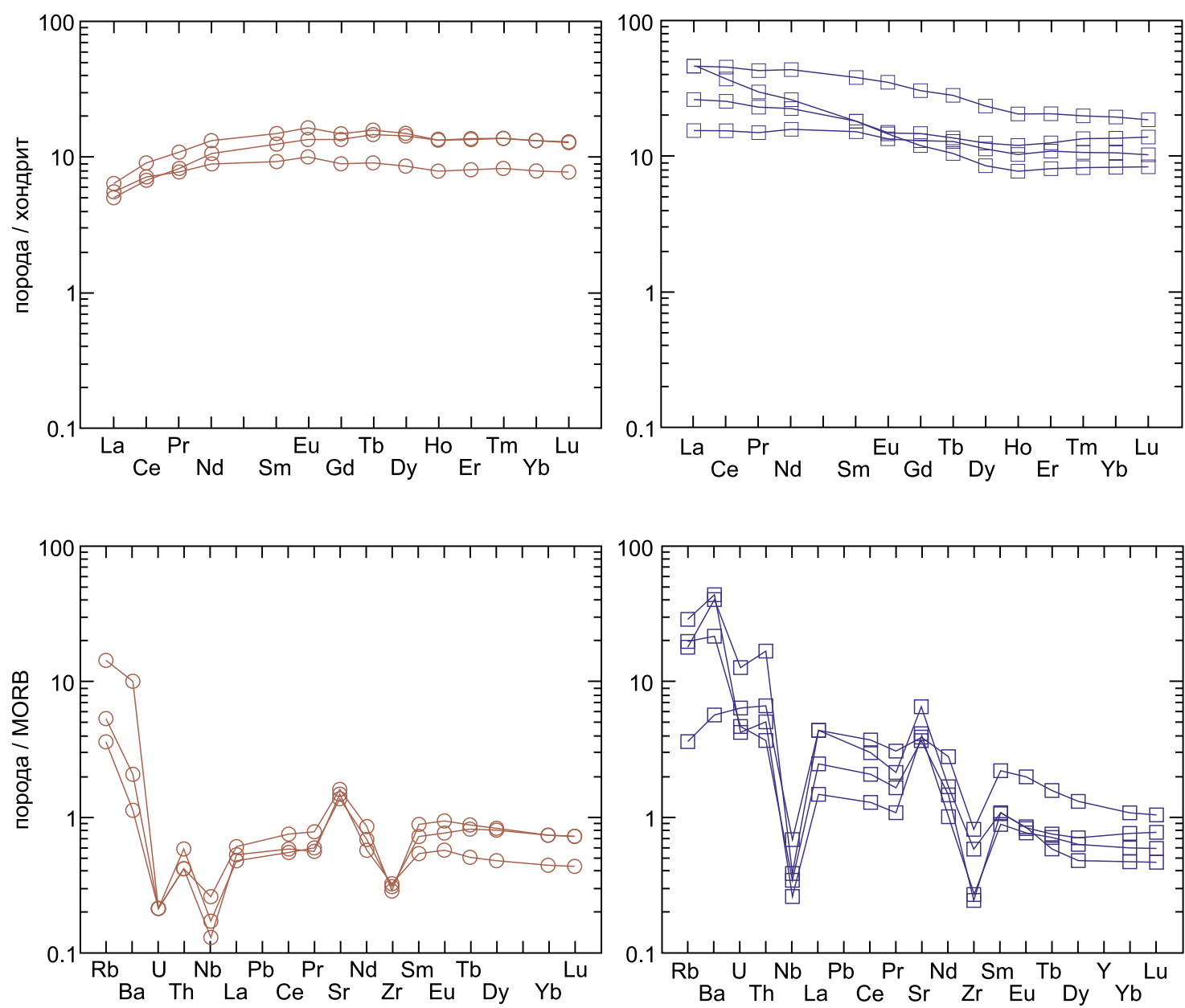

Рис. 9. Геохимические особенности двух главных типов пород габбрового комплекса Войкарских офиолитов.

Fig. 9. Geochemical features of two major rock types of the Voikar ophiolites gabbro complex.

ми и примитивными габброидами, произошедшими за счет расплавов типа MORB. Они слагают Нижний мегаритм и Переходную зону, а также матрицу Верхнего мегаритма.

С такой последовательностью событий согласуются и данные $\mathrm{Sm}-\mathrm{Nd}$ и $\mathrm{Re}-\mathrm{Os}$ изотопии пород войкарских офиолитов, указывающие на заметные различия между материалом Нижнего и Верхнего мегаритмов. Так, в габбро-норитах последнего устанавливается присутствие древнего вещества, а величина ${ }^{187}$ Os/1880s отношения составляет 6.5-7.1, что на порядок выше, чем в мантийных породах ассоциации, и в два раза выше, чем в диабазах комплекса параллельных даек [Sharma et al., 1998]. Мантийные реститы, как и реститы Атлантики, формировались в поле стабильности гранатового лерцолита, причем один из образцов гарцбургита образован древним материалом [Sharma et al., 1995].

O неоднородности вещества мантийного комплекса также свидетельствуют находки циркона с возрастом от 0.6 до 1.9-2.0 млрд лет (U-Pb метод) в высокохромистых хромитах в мантийных перидо- титах [Savelieva et al., 2013]. Предполагается, что эти датировки могут отражать время частичного плавления перидотитов и/или взаимодействия перидотитов с мигрировавшими сквозь них расплавами типа MORB.

Таким образом, судя по геологическим, изотопным и изотопно-геохронологическим данным, реститовый мантийный комплекс войкарских офиолитов формировался существенно раньше Габбрового, который, в свою очередь, образовался в процессе нескольких эпизодов тектономагматической активности.

Отсутствие скрытой расслоенности в породах Войкарского расслоенного габбрового комплекса может свидетельствовать о том, что формирование обоих мегаритмов происходило при периодической подпитке интрузивных камер порциями свежих магм из мантийного источника [Sharkov et al., 2001]. В таких условиях эти камеры в каждый конкретный момент могли представлять собой сравнительно маломощные линзы, подстилаемые «хвостом» затвердевшего горячего материала. 
Из всех этих данных следует ряд выводов:

1) океаническая кора задугового «Войкарского» моря подстилалась деформированными более древними деплетированными перидотитами мантийного комплекса, среди которых встречен образец с древними изотопными характеристиками, а в хромитах из дунитов комплекса - зерна циркона с палеопротерозойскими датировками;

2) образование нижней коры (габбрового комплекса) здесь происходило по крайней мере в два главных этапа, причем более ранний характеризуется присутствием тел габбро-норитов, произошедших за счет расплавов надсубдукционной известково-щелочной серии;

3) судя по относительно хорошей сохранности разрезов расслоенных интрузивов габбрового комплекса, их становление происходило во времена относительного затишья тектонических процессов;

4) наблюдаются заметные различия в изотопии между главными составляющими офиолитовой ассоциации: мантийными породами, комплексом параллельных даек и двумя мегаритмами габбрового комплекса, причем в габбро-норитах более раннего зафиксировано присутствие древнего материала.

\section{5. ОБСУЖДЕНИЕ}

Приведенные данные по впадине Маркова, расположенной в зоне современного спрединга САХ, и палеозойским войкарским офиолитам, формировавшимся в условиях задугового моря, могут свидетельствовать о том, что нижняя океаническая кора в обоих случаях сложена преимущественно сильно измененными интрузивами мафит-ультрамафитов, которые образовались существенно раньше верхней коры, где преобладают свежие пиллоулавы. Как видно на примере Войкарского габбрового комплекса, основным механизмом формирования нижней коры был неоднократный андерплейтинг расплавов типа MORB, зарождавшихся в астеносфере; они накапливались вдоль существовавшей тогда границы кора - мантия и затвердевали в форме крупных расслоенных мафит-ультрамафитовых интрузивов. При этом нижележащие мантийные ультрабазиты, судя по геологическим и изотопно-геохронологическим данным, формировались намного раньше нижней коры.

Поскольку во впадине Маркова, как и в других ВОК медленно-спрединговых хребтов [Searle, 2013], образования нижней коры современных океанов также располагаются непосредственно на мантийных перидотитах, ее формирование там, вероятно, тоже происходило путем андерплейтинга.

Кроме того, судя по изученным примерам, нижняя кора и в океанах, и в задуговых морях наращи- валась многократными внедрениями магм из самостоятельных источников. Имеются в виду силлообразные интрузивные тела феррогабброидов, произошедшие из расплавов типа ОIB в случае ВОК Сьерра-Леоне, и габбро-норитов ранних стадий развития Войкарского габбрового комплекса, связанных с островодужными известково-щелочными магмами. В первом случае это, скорее всего, было связано с влиянием мантийного плюма под ВОК Сьерра-Леоне [Schilling et al., 1994; Sharkov, 2012], а во втором, по-видимому, определялось формированием Войкарских офиолитов над зоной субдукции.

Из полученных данных также следует, что расслоенная текстура нижней океанической коры в обоих случаях связана как с первичной магматической расслоенностью крупных мафит-ультрамафитовых интрузивов, так и с внедрением силлообразных интрузивных тел в уже существовавшую к этому времени нижнюю кору. Обращает на себя внимание, что и там, и там нижележащая мантия сложена истощенными перидотитами - преимущественно гарцбургитами и меньше - истощенными лерцолитами, а основная масса коры, ее матрица однотипными расслоенными интрузивами, что предполагает сходство плавившихся субстратов.

Судя по данным Sm-Nd изотопии, в частности линейной ${ }^{147} \mathrm{Sm} /{ }^{144} \mathrm{Nd}-{ }^{143} \mathrm{Nd} /{ }^{144} \mathrm{Nd}$ корреляции, океанические коровые породы и мантийные гарцбургиты в хорошо сохранившихся Войкарских офиолитах произошли из источника MORB при сепарации расплава в поле стабильности гранатового лерцолита [Sharma et al., 1995]. Как отмечалось выше, эти перидотиты испытали интенсивные деформации еще до внедрения расплавов, формировавших габбровый комплекс, т.е. не являются его реститами, а представляют собой более древние образования. С геологическими данными согласуются и данные Os изотопии (см. выше), а также результаты датирования циркона из хромитов перидотитов Войкара [Savelieva et al., 2013]. Иными словами, здесь и породы океанической коры, и мантийные реститы, хоть и произошли из источников MORB, но генетически не связаны друг с другом [Sharma et al., 1995, 1998].

Такими же по составу катаклазированными перидотитами (преимущественно гарцбургитами) сложены мантийные породы во впадине Маркова. Здесь они являются частью гомогенной деплетированной верхней мантии Атлантики, в которых наблюдается примесь реститов древнего плавления, происходившего, как и в случае Войкара, в условиях стабильности граната [Andres et al., 2004]. На основе данных по изотопии Нf эти исследователи пришли к выводу, что формирование таких реститов происходило в астеносфере континентов не менее 1 млрд лет назад, задолго до раскрытия Ат- 
лантики. Иными словами, породы мантии, непосредственно подстилающей океаническую кору, древнее ее и генетически не связаны ни с габброидами, ни, тем более, с современными базальтами. Как уже говорилось, мантийные перидотиты здесь, как и в других ВОК [Searle, 2013], непосредственно перекрываются габброидами океанической нижней коры, что предполагает андерплейтинг как ведущий механизм формирования нижней коры океана.

О возрасте этой коры в настоящее время судить сложно. Согласно результатам U-Pb SHRIMP-II изотопного датирования зерен циркона, извлеченного из габброидов САХ, этот возраст варьируется в очень широких пределах - от 0.7 до 3117 млн лет [Bortnikov et al., 2008; Skolotnev et al., 2010]. Если откинуть заведомо аномальные датировки в миллиарды лет, связанные с ксеногенными зернами циркона, формирование нижней коры океана могло начаться существенно раньше и продолжается в настоящее время в условиях океанического спрединга, т.е. симметричного растекания коры от его оси. Как следует из приведенных данных, механизм этого спрединга намного сложнее, чем это предполагалось авторами классической Пенроузской модели полвека назад.

Фиксируемое во впадине Маркова (и других ВОК) перекрытие сильно измененных плутонических мафит-ультрамафитов потоками свежих базальтов предполагает существенный разрыв во времени между ними, сопровождавшийся структурно-метаморфической переработкой нижней коры и верхов мантии. Продолжительность этого разрыва неизвестна, но, вероятно, составляла не менее 1-2 млн лет. Судя по изотопно-геохимическим данным, разрыв во времени можно предполагать и между плутонитами и вулканитами Войкара.

Таким образом, в обоих случаях формирование нижней океанической коры происходило по сходному сценарию. Она развивалась на фундаменте, сложенном деплетированными перидотитами литосферной мантии, путем неоднократного андерплейтинга расплавов типа MORB, а также внедрения силлообразных интрузивов в уже существующую нижнюю кору. В современных ВОК, согласно данным по впадине Маркова (САХ), эти тела представлены феррогабброидами, образовавшимися с участием расплавов ОIB, а в случае задуговых морей, судя по верхнему мегаритму габбрового комплекса войкарских офиолитов, - габбро-норитами, связанными, скорее всего, с надсубдукционной известково-щелочной серией.

Верхняя кора в обоих случаях образована преимущественно более поздними излияниями базальтов. При этом, как следует из данных по впа- дине Маркова, значительная часть нижней коры и верхов мантии испытала к этому времени процессы наложенных деформаций и метаморфизма в условиях зеленосланцевой фации. Из всего этого следует, что наблюдаемая здесь нижняя кора является частью более древней океанической литосферы и в основном образовалась в предшествующий эпизод (эпизоды?) тектономагматической активности. Она была поднята на уровень современного дна океана вместе с подстилающими ее мантийными перидотитами существенно позже, уже в связи с современным эпизодом развития ВОК СьерраЛеоне.

\section{1. ОСОБЕННОСТИ ФОРМИРОВАНИЯ НИЖНЕЙ КОРЫ СОВРЕМЕННЫХ МЕДЛЕННО-СПРЕДИНГОВЫХ ХРЕБТОВ}

Как уже говорилось, происхождение ВОКов в настоящее время часто связывается с существованием крупных внеосевых океанических разломов срыва (оceanic detachment faults [Ildefonse et al., 2007; MacLeod et al., 2009; Conference..., 2010; Searle, 2013, и ссылки в этих работах]) (рис. 10).

Несмотря на свою популярность, эта модель остается весьма дискуссионной и вызывает много вопросов, в частности о причине подъема территории, возникновении разрывов срыва, их морфологии, источниках гидротермальных флюидов и т.д. В рамках данной работы проблема происхождения ВОК специально не обсуждается. Отметим только, что, по-нашему мнению, такие структуры возникают в результате подъема мантийных плюмов в осевой части хребта (рис. 11). Они достигают границы астеносфера - океаническая литосфера и приподнимают ее с образованием куполообразных поднятий, что сопровождается базальтовым вулканизмом, связанным с адиабатическим плавлением головы плюма, и появлением гидротермальных полей [Sharkov, 2012]. Судя по форме ВОКов, головные части этих мантийных плюмов не были изометричными в плане, а имели вытянутую форму, частично приспосабливаясь к структуре срединноокеанического хребта. Надо сказать, что и на континентах мантийные плюмы далеко не всегда представляют собой изометричные в плане структуры, а судя по развитию связанных с ними крупных изверженных провинций, часто имеют сложную морфологию [Ernst, 2014].

Подъем астеносферы приводит к возобновлению ее адиабатического плавления и последующему объединению обоих типов зон генерации магм (плюмового и астеносферного), с формированием специфических расплавов кремнеземистой Fe-Ti-оксидной серии, в образовании которых участвуют и процессы ассимиляции более древней гидратированной коры (см. выше). 


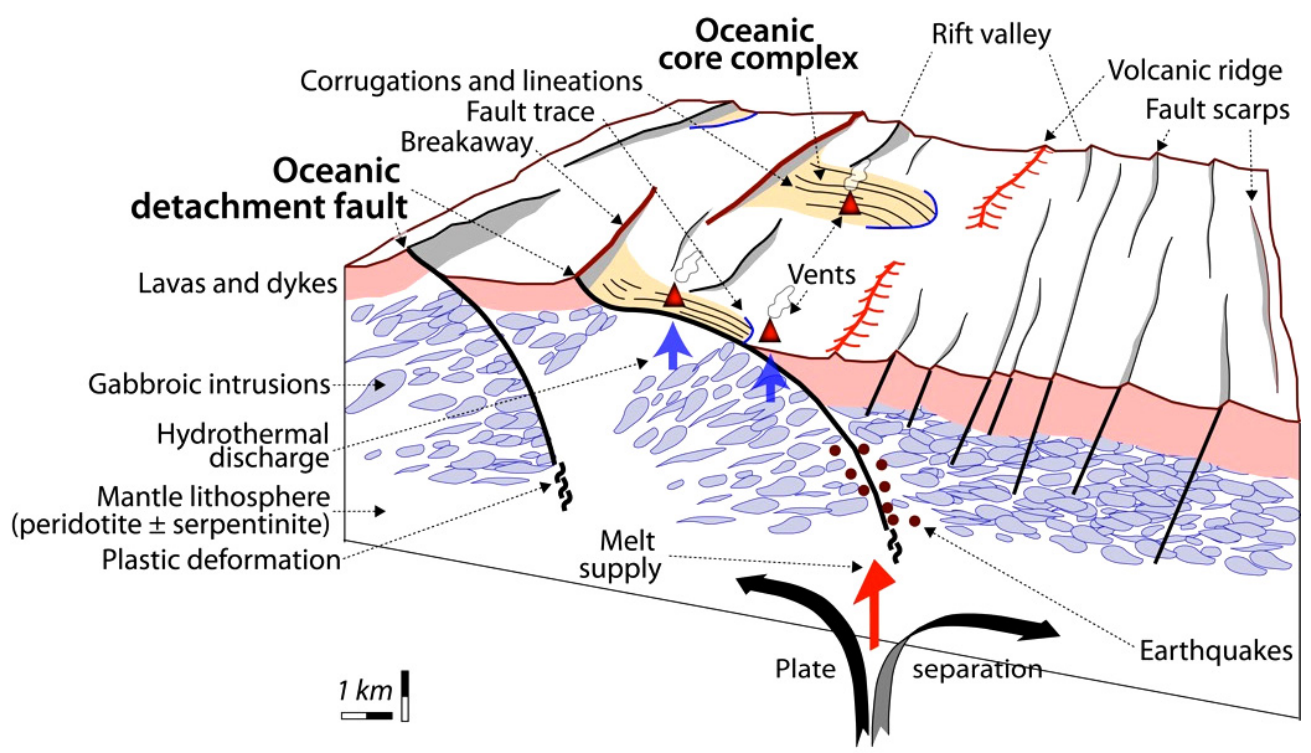

Рис. 10. Схема строения внутреннего океанического комплекса (осеапic core complex) с внеосевым океаническим разломом срыва (oceanic detachment fault), по [Conference..., 2010].

Fig. 10. Structure of the oceanic core complex with the off-axis oceanic detachment fault (after [Conference..., 2010]).

В случае ВоК Сьерра-Леоне существование мантийного плюма под ним следует из общего подъема территории, из изотопных данных [Schilling et al., 1994], из наличия силлообразных тел феррогабброидов, формировавшихся при участии расплавов OIB, из следов гидротермальных систем [Sharkov et al., 2007], а также из состава свежих пиллоу-лав, где преобладают расплавы типа T-MORB и E-MORB, характерные для участков хребтов в районе проявлений плюмового магматизма [Basaltic Volcanism..., 1981]. Скорее всего, аналогичные тектономагматические процессы в настоящее время происходят и под другими ВОКами. Об этом могут свидетельствовать находки современных магматических оча- гов под этими структурами [Dunn et al., 2005, 2016], наличие гидротермальных полей (действующих и реликтовых) и присутствие современного базальтового вулканизма.

ВОКи протягиваются неправильной цепью вдоль всего САХ, составляя около 30 \% его протяженности [Escartín et al., 2008; MacLeod et al., 2009, и ссылки в этих работах], постепенно сменяясь участками нормального спрединга между ними. Факт перекрытия свежими базальтами более древних сильно измененных плутонических пород ВОКов свидетельствует о том, что они генетически не связаны друг с другом, т.е. процесс океанического спрединга не был непрерывным, а происходил пульсами и не (a)

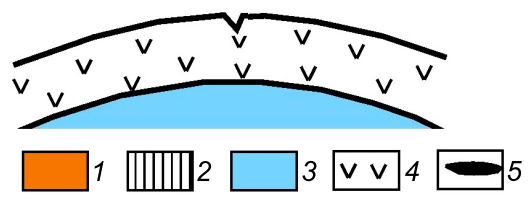

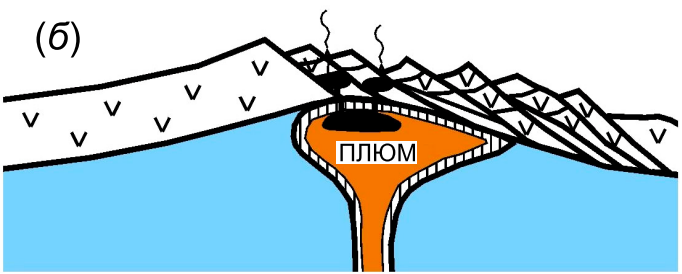

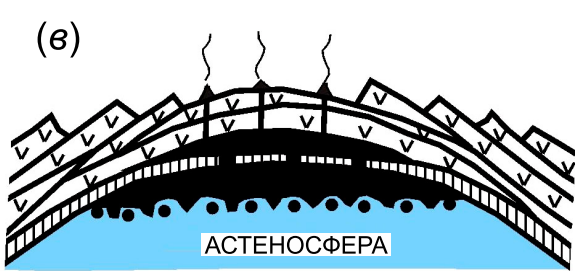

Рис. 11. Схема, иллюстрирующая возникновение и развитие ВОК в осевой части САХ: $(a)$ - исходное состояние; (б) - инициальная стадия (образование ВОК, односторонний спрединг); (в) - переход к билатеральному спредингу (по [Sharkov, 2012]).

1 - головная часть мантийного плюма; 2 - его охлажденные края; 3 - астеносфера; 4 - океаническая литосфера; 5 - базальтовый расплав: внизу - зоны плавления, вверху - участвующий в формировании нижней коры.

Fig. 11. Occurrence and development of the oceanic core complex in the axial part of the Mid-Atlantic Ridge: $(a)$ - original state; (б) - initial stage (formation of OCC, unilateral spreading); ( 8 ) - transition to bilateral spreading (after [Sharkov, 2012]).

1-2 - mantle plume (1 - head; 2 - cooled margins); 3 - asthenosphere; 4 - oceanic lithosphere; 5 - basalt melt. 
одновременно по всей длине хребта. По-видимому, эти территориально разобщенные ВОКи и представляют собой сегменты хребта, где происходит возобновление процессов спрединга, которые в дальнейшем разовьются в зоны нормального океанического спрединга с мощным базальтовым магматизмом [Sharkov, 2012]. Как уже говорилось, судя по наличию полосовых магнитных аномалий, перерывы между пульсами активности могли быть небольшими, порядка 1-2 млн лет.

Согласно расчетным данным [Girnis, 2003], плавление источника MORB происходит при давлении 8-10 кбар, т.е. в интервале глубин 25-30 км, а возможно, и глубже - 50-100 км [Lagmuir, Forsyth, 2007]. Новообразованный базальтовый расплав на стадии ВОК поднимался в форме даек сквозь литосферную мантию и частично наращивал существующую нижнюю кору в форме силлов, а по мере дальнейшего развития процессов спрединга и усиления сопутствующего ему магматизма в данном сегменте хребта наращивание нижней коры происходило снизу, путем андерплейтинга. Новообразованные реститы, в свою очередь, наращивали снизу литосферную мантию.

В отличие от суши, где подъем территории сопровождается интенсивной эрозией, приводящей в итоге к выведению глубинных пород на поверхность, на дне океана этот фактор не действует. Сам факт того, что глубинные плутонические породы оказались на дне океана, свидетельствует о том, что подъем оси спрединга в ВОКах медленноспрединговых хребтов был весьма значительным и сопровождался эффективной тектонической эрозией (гравитационным оползанием тектонических пластин корового материала со склонов растущего купола). Этим, вероятно, и объясняется небольшая мощность наблюдаемой нижней коры.

\section{2. ОСОБЕННОСТИ ФОРМИРОВАНИЯ НИЖНЕЙ КОРЫ ЗАДУГОВОГО БАССЕЙНА}

Приведенные данные по Войкарской офиолитовой ассоциации свидетельствуют о том, что и формирование нижней коры задуговых морей, по крайней мере в рассмотренном случае, происходило по сходному сценарию. Она также развивалась на фундаменте, сложенном деплетированными перидотитами литосферной мантии путем неоднократного андерплейтинга расплавов типа MORB, возникших за счет сходных с плавящимися протолитами океана астеносферных субстратов, а также внедрения дайко- и силлообразных интрузивов, произошедших за счет надсубдукционных магм. Таким образом, основные различия в составе нижней океанической коры срединно-океанических хребтов и задуговых морей заключаются именно в отсутствии или наличии продуктов надсубдукционного магматизма. Все это предполагает существенную общность состава и физических свойств мантии под океанами и задуговыми морями, что подтверждается и геофизическими, и экспериментальными данными [Vasco et al., 1994; Kirdyashkin A.A., Kirdyashkin A.G., 2013]. Иными словами, весьма вероятно, что под задуговыми морями развита та же самая океаническая астеносфера, «отшнурованная» от океана зоной субдукции.

Проблеме формирования систем вулканическая дуга - задуговое море посвящено множество работ, в том числе [Wilson, 1989; Dobretsov et al., 2001; Turcotte, Schubert, 2002; Philpotts, Ague, 2009, и ссылки в этих работах]. Большинство исследователей полагает, что образование таких морей происходит в результате задугового спрединга, сопровождающегося откатом (rollback) зон субдукции и связанного с ними магматизма (вулканических дуг) в сторону океана. Предлагаются разнообразные механизмы такого отката, например последовательное погружение в мантию участков толстого и холодного океанического слэба [Molnar, Atwater, 1978], нарушение динамического равновесия при стагнации слэба [Zorin et al., 2007], конвективные течения, индуцируемые как самим движением субдукцирующего слэба [Turcotte, Schubert, 2002], так и его охлаждающим влиянием [Dobretsov et al., 2001] и т.д. Однако эта проблема до сих пор далека от разрешения.

С нашей точки зрения, ситуация здесь выглядит следующим образом (рис. 12). Растекающаяся океаническая астеносфера затекает под край соседнего континента, отчленяет от него некий фрагмент и начинает накапливаться за ним, постепенно сдвигая его в сторону океана и приводя к явлению задугового спрединга [Bogatikov et al., 2010; Sharkov, Svalova, 2011]. Иными словами, именно глубинные процессы в задуговых морях играют ключевую роль в системах дуга - задуговое море. Задуговый спрединг сопровождался разрывами и постепенным утонением снизу бывшей здесь ранее континентальной коры, фрагменты которой транспортируются астеносферным течением в сторону зоны субдукции, где необратимо вовлекаются в нисходящее движение материала (рис. 12). В результате для задуговых морей характерна утоненная кора мощностью 15-20 км.

Параллельно с деструкцией старой континентальной коры в результате такой своеобразной «сублитосферной эрозии» происходит образование новой океанической коры за счет собственно задугового магматизма, обусловленного адиабатическим плавлением верхов астеносферы. Этим, повидимому, и объясняется последовательность событий при образовании разреза габбрового ком- 


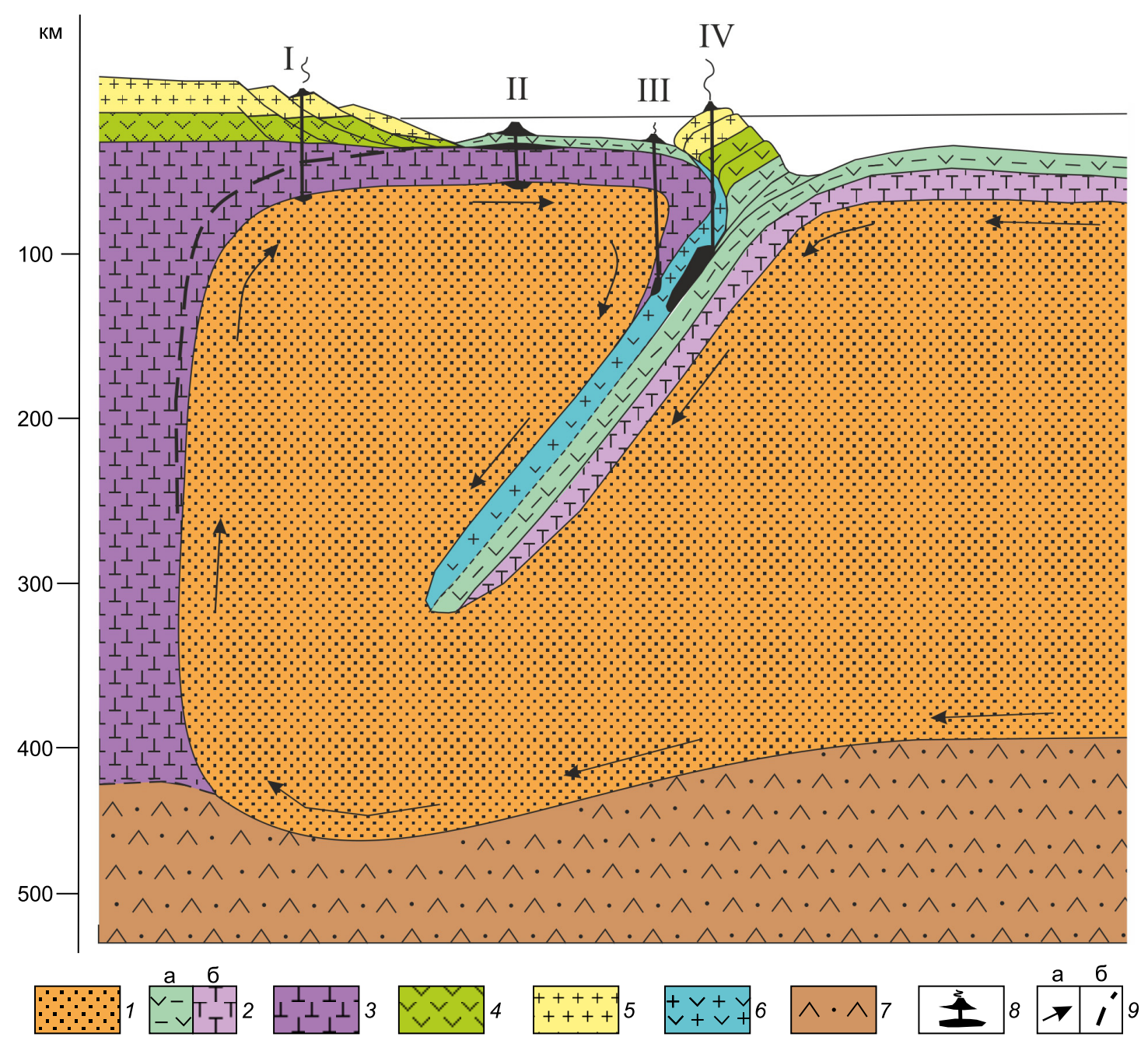

Рис. 12. Схема, иллюстрирующая ранние стадии развития процесса задугового спрединга.

1 - вещество океанической астеносферы; 2 - вещество океанической литосферы: а - коры (в том числе и задугового моря), б - мантии; 3-5 - вещество континентальной литосферы: 3 - мантии, 4 - нижней (мафитовой) коры, 5 - материал верхней (сиалической) коры; 6 - смесь вещества сиалической и базитовой коры в зоне субдукции; 7 - вещество средней мантии; 8 - области генерации магм; 9 - движение материала: а - направление течения океанической верхней мантии в системе океан - зона субдукции - задуговое море, б - примерный контур материала литосферной мантии, вовлекаемого в подъем течением задугового «затека» астеносферы. Цифры на рисунке: I - магматизм в рифтогенных структурах в тылу задугового моря; II - образования толеитовой серии; III - бонинитовой серии; IV - известково-щелочной серии.

Fig. 12. Diagram illustrating the early stages of back-arc spreading.

1 - oceanic asthenosphere material; 2 - oceanic lithosphere material: a - crust (including the back-arc sea), 6 - mantle; 3-5 - continental lithosphere material: 3 - mantle, 4 - lower (mafic) crust, 5 - upper (sialic) crust material; 6 - mixture of the sialic and basic crust materials in the subduction zone; 7 - middle mantle material; 8 - magma generation zones; 9 - movement of the materials: a - direction of the oceanic upper mantle flow in the 'ocean - areas of subduction - back-arc sea' system, $\sigma$ - rough contour of the lithospheric mantle material involved in the rise caused by the back-arc 'streaks' of the asthenosphere material. Numbers in the figure: I - magmatism in rift structures in the rear of the back-arc sea; II - tholeiitic series; III - boninite series; IV - calc-alkaline series.

плекса Войкара. Как уже говорилось, формирование нижней коры здесь происходило по такому же принципу, как и в медленно-спрединговых хребтах, путем андерплейтинга. Удаление старой континентальной коры и развитие здесь базальтового магматизма должно приводить к появлению в задуговом море вначале участков с океанической корой, как это хорошо видно на примере Японского моря, а в конечном итоге - к ее преобладанию, примером чему является Филиппинское море [Bogdanov, 1988].

Такой характер тектономагматических процессов в задуговых морях описывается как диффузный, или рассеянный, спрединг [Bogdanov, 1988], отличающийся отсутствием линейной рифтовой долины, как это имеет место в океанах.

Встречное движение материала астеносферы задугового моря с одной стороны и океана с другой 
должно было приводить к появлению вдоль границы с океанической плитой мощной зоны сжатия [Dobretsov et al., 2001]. В результате весь этот литосферный материал (включая верхнюю кору континентов) уплотняется и метаморфизуется вплоть до появления высокоплотных гранатовых гранулитов и эклогитов, благодаря чему дальнейшее нисходящее течение материала происходит уже под влиянием гравитации. В подобной ситуации в мантию буквально «засасываются» породы континентальной литосферы из задугового пространства, и в то же время - материал океанической литосферы с образованием зоны нисходящего течения в мантию - зону субдукции. Все это сопровождается появлением существенно андезит-латитовой вулканической дуги, возникшей за счет плавления мантийно-коровых протолитов [Bogatikov et al., 2010]. Иными словами, задуговый бассейн с базальтовым магматизмом и утоненной корой промежуточного или океанического типа, вулканическая дуга и прилегающая часть океана, по-видимому, представляют собой взаимосвязанную и взаимообусловленную систему. Вероятнее всего, именно этим и объясняется сходство в составе и развитии коры океанов и задуговых морей.

В этой связи необходимо остановиться на происхождении литосферной мантии, подстилающей габбровый комплекс Войкара. Она образована сильно деплетированными перидотитами с высоковарьирующимся $\varepsilon \mathrm{Nd}$ при очень низких содержаниях $\mathrm{Nd}$ [Sharma et al., 1995]; эти перидотиты к тому же характеризуются древними полихронными U-Pb изотопными датировками по циркону [Savelieva et al., 2013]. Скорее всего, эта мантия представляла собой смесь материала древней истощенной литосферной мантии континента, вовлекаемого в движение поднимающимся веществом астеносферы (рис. 12).

\section{6. ЗАКЛЮЧЕНИЕ}

На примере впадины Маркова (осевая часть медленно-спредингового Срединно-Атлантического хребта, $6^{\circ}$ с.ш., внутренний океанический комплекс Сьерра-Леоне) и палеозойской Войкарской офиолитовой ассоциации (Полярный Урал), формировавшейся в условиях задугового моря, показано, что в обоих случаях эта кора имеет сходное строение и формировалась на более древнем фундаменте, сложенном деплетированными перидотитами литосферной мантии не совсем ясного происхождения - континентального или океанического.

Согласно имеющимся данным, ведущую роль в составе нижней коры океанов и задуговых морей играют расслоенные мафит-ультрамафитовые интрузивы, произошедшие преимущественно из рас- плавов типа MORB, что предполагает сходный астеносферный источник магм.

Во впадине Маркова измененные тектонизированные плутонические породы океанической литосферы (габброиды нижней коры и подстилающие их серпентинизированные мантийные перидотиты) несогласно перекрываются потоками свежих базальтов с корками закалочного вулканического стекла. Это предполагает существенную разницу во времени их образования и отсутствие генетической взаимосвязи между формированием современной верхней базальтовой коры и плутоническими породами нижней коры. В случае войкарских офиолитов наблюдаются существенные различия в изотопии между образованиями нижней и верхней коры, что также может свидетельствовать о их возникновении в разные эпизоды развития задугового моря. Иными словами, формирование нижней коры в медленно-спрединговых хребтах и задуговых морях происходило по сходному сценарию.

Также в обоих случаях формирование основной массы нижней коры происходило в основном путем накопления базальтовых магм типа MORB вдоль границы кора-мантия (андерплейтинг) в форме расслоенных интрузивов. При этом, судя по габбровому комплексу Войкара, таких эпизодов становления нижней коры было по крайней мере два. Отсутствие возможности построения систематического разреза нижней коры во впадине Маркова не позволяет сделать определенные выводы на этот счет в случае рассмотренного сегмента СAX, хотя и здесь не исключено существование нескольких эпизодов ее формирования.

В обоих случаях нижняя кора подстилается сильно серпентинизированными деплетированными ультрамафитами литосферной мантии, сложенной главным образом гарцбургитами, реже - лерцолитами. Согласно геологическим, изотопным и изотопно-геохронологическим данным по Войкару, а также изотопным данным по мантийным перидотитам Атлантики, формирование подобной мантии могло происходить задолго до образования нижней океанической коры, в поле стабильности гранатового лерцолита.

Главное различие между нижней корой современного океана, рассмотренной на примере впадины Маркова (СAX), и корой задугового моря (Войкар) заключается в присутствии в последней тел габбро-норитов, связанных с надсубдукционной известково-щелочной серией. Судя по наличию габбро-норитов в нижней коре Филиппинского моря, присутствие этих пород является типоморфной особенностью подобных тектонических структур.

Предполагается, что внутренние океанические комплексы CAX, в том числе и Сьерра-Леоне, а так- 
же других медленно-спрединговых хребтов, представляют собой их сегменты, где начинаются процессы возобновления спрединга, которые в дальнейшем разовьются в зоны нормального спрединга с мощным базальтовым магматизмом. На стадии ВОК новообразованный базальтовый расплав поднимается из зоны генерации магм по трещинам (дайкам) сквозь литосферную мантию и частично наращивает существующую нижнюю кору в форме силлов; по мере развития магматизма наращивание происходит снизу, путем андерплейтинга. Но- вообразованные реститы, в свою очередь, наращивают снизу литосферную мантию.

\section{7. БЛАГОДАРНОСТИ}

Автор выражает глубокую признательность академику Н.С. Бортникову (ИГЕМ РАН, Москва) за постоянный интерес к геологии дна океана и конструктивное обсуждение проблем Мирового океана.

\section{8. ЛИТЕРАTУPA / REFERENCES}

Andres M., Blichert-Toft J., Schilling J.G., 2004. Nature of the depleted upper mantle beneath the Atlantic: evidence from $\mathrm{Hf}$ isotopes in normal mid-ocean ridge basalts from $79^{\circ} \mathrm{N}$ to $55^{\circ} \mathrm{S}$. Earth and Planetary Science Letters 225 (1-2), 89-103. https://doi.org/10.1016/j.epsl.2004.05.041.

Aranovich L.Ya., Bortnikov N.S., Serebryakov N.S., Sharkov E.V., 2010. Conditions of the formation of plagiogranite from the Markov Trough, Mid-Atlantic Ridge, $5^{\circ} 52^{\prime}-6^{\circ} 02^{\prime}$ N. Doklady Earth Sciences 434 (1), 1257-1262. https:// doi.org/10.1134/S1028334X10090254.

Basaltic Volcanism on the Terrestrial Planets, 1981. Pergamon Press, New York, 1286 p.

Bogatikov O.A., Kovalenko V.I., Sharkov E.V., 2010. Magmatism, Tectonics, and Geodynamics of the Earth. Nauka, Moscow, 606 p. (in Russian) [Богатиков О.А., Коваленко В.И., Шарков Е.В. Магматизм, тектоника, геодинамика Земли. М.: Наука, 2010. 606 с.].

Bogdanov N.A., 1988. Tectonics of Deep-Water Basins of Marginal Seas. Nedra, Moscow, 221 p. (in Russian) [Богдaнов Н.A. Тектоника глубоководных впадин окраинных морей. М.: Недра, 1988, 221 с.].

Bortnikov N.S., Sharkov E.V., 2011. Oceanic core complex and newly-formed basalts in axial part of Mid-Atlantic Ridge (5-7º N). In: 2011 AGU Fall Meeting (5-9 December, 2011). San Francisco, California, USA, Paper Number OS11B-1499.

Bortnikov N.S., Sharkov E.V., Bogatikov O.A., Zinger T.F., Lepekhina E.N., Antonov A.V., Sergeev S.A., 2008. Finds of young and ancient zircons in gabbroids of the Markov Deep, Mid-Atlantic Ridge, $5^{\circ} 54^{\prime}-5^{\circ} 02.2^{\prime} \mathrm{N}$ (Results of SHRIMP-II $\mathrm{U}-\mathrm{Pb}$ dating): Implication for deep geodynamics of modern oceans. Doklady Earth Sciences 421 (1), 859-866. https://doi.org/10.1134/S1028334X08050334.

Ciazela J., Koepke J., Dick H.J., Muszynski A., 2015. Mantle rock exposures at oceanic core complexes along mid-ocean ridges. Geologos 21 (4), 207-231. https://doi.org/10.1515/logos-2015-0017.

Conference Outline, 2010. In: Detachments in oceanic lithosphere: deformation, magmatism, fluid flow, and ecosystems. AGU Chapman Conference. Agros, Cyprus, 8-15 May, 2010. Conference Report, p. 20-21.

Crawford A.J., Fallon T.J., Green D.H., 1989. Classification, petrogenesis and tectonic setting of boninites. In: A.J. Crawford (Ed.), Boninites and related rocks. Unwin Hyman, London, p. 2-44.

Dick H.J.B., Robinson P.T., Meyers P.S., 1992. The plutonic foundation of a low-spreading ridge. In: R.A. Duncan, D.K. Rea, R.B. Kidd, U. von Rad, J.K. Weissel (Eds.), Synthesis of results from scientific drilling in the Indian ocean. Geophysical Monograph Series, vol. 70, p. 1-39. https://doi.org/10.1029/GM070p0001.

Dick H.J.B., Tivey M.A., Tucholke B.E., 2008. Plutonic foundation of a slow-spreading ridge segment: Oceanic core complex at Kane Megamullion, $23^{\circ} 30^{\prime} \mathrm{N}, 45^{\circ} 20^{\prime}$ W. Geochemistry, Geophysics, Geosystems 9 (5), Q05014. https:// doi.org/10.1029/2007GC001645.

Dilek Y., Furnes H., 2011. Ophiolite genesis and global tectonics: Geochemical and tectonic fingerprinting of ancient oceanic lithosphere. Geological Society of America Bulletin 123 (3-4), 387-411. https://doi.org/10.1130/ B30446.1.

Dobretsov N.L., Kirdyashkin A.G., Kirdyaskin A.A., 2001. Deep-Level Geodynamics. Novosibirsk, Siberian Branch of the RAS Publishing House, “Geo" Branch, 407 p. (in Russian) [Добрецов Н.Л., Кирдяшкин А.Г., Кирдяшкин А.А. Глубинная геодинамика. Новосибирск: Изд-во СО РАН, филиал «Гео», 2001. 407 с.].

Dunn R.A., Arai R., Eason D.E., Canales J.P., Sohn R.A., 2016. 3-D seismic imaging of lithospheric fault-block structures, core complex, alteration fronts, and hydrothermal system along the Mid-Atlantic Ridge, Rainbow area. In: AGU Fall Meeting (12-18 December, 2016). San Francisco, California, USA, Paper Number T32A-08.

Dunn R.A., Lekić V., Detrick R.S., Toomey D.R., 2005. Three-dimensional seismic structure of the Mid-Atlantic Ridge $\left(35^{\circ} \mathrm{N}\right)$ : Evidence for focused melt supply and lower crustal dike injection. Journal of Geophysical Research: Solid Earth 110 (B9), B09101. https://doi.org/10.1029/2004JB003473. 
Ernst R.E., 2014. Large Igneous Provinces. Cambridge University Press, Cambridge, 653 p.

Escartín J., Smith D.K., Cann J., Schouten H., Langmuir C.H., Escrig S., 2008. Central role of detachment faults in accretion of slow-spreading oceanic lithosphere. Nature 455 (7214), 790-795. https://doi.org/10.1038/nature07333.

Estrada S., Henjes-Kunst F., Burgath K.P., Roland N.W., Schäfer F., Khain E.V., Remizov D.N., 2012. Insights into the magmatic and geotectonic history of the Voikar Massif, Polar Urals. Zeitschrift der Deutschen Gesellschaft für Geowissenschaften 163 (1), 9-41. https://doi.org/10.1127/1860-1804/2012/0163-0009.

Girnis A.V., 2003. Olivine-orthopyroxene-melt equilibrium as a thermobarometer for mantle-derived magmas. Petrology 11 (2), 101-113.

Ildefonse B., Blackman D.K., John B.E., Ohara Y., Miller D.J., MacLeod C.J., 2007. Oceanic core complexes and crustal accretion at slow-spreading ridges. Geology 35 (7), 623-626. https://doi.org/10.1130/G23531A.1.

Kirdyashkin A.A., Kirdyashkin A.G., 2013. Experimental and theoretical simulation of the thermal and hydrodynamic structure of a subducting plate. Geotectonics 47 (3), 156-166. https://doi.org/10.1134/S0016852113030047.

Knipper A.L., Sharaskin A.Y., Savelieva G.N., 2001. Geodynamic factors responsible for origin of diverse ophiolite sequences. Geotectonics 35 (4), 247-264.

Kurenkov S.A., Didenko A.N., Simonov V.A., 2002. Geodynamics of Paleospreading. GEOS, Moscow, 294 p. (in Russian) [Куренков С.А., Диденко А.Н., Симонов В.А. Геодинамика палеоспрединга. М.: ГЕОС, 2002. 294 с.].

Langmuir C.H.L., Forsyth D.W., 2007. Mantle melting beneath mid-ocean ridges. Oceanography 20 (1), 78-89. https:// doi.org/10.5670/oceanog.2007.82.

Laz'ko E.E., Gladkov N.G., 1991. Ultrabasites and gabbroids of the Aypod Depression (Yap Fault, Philippine Sea). Izvestiya AN SSSR, Geological Series (6), 47-65 (in Russian) [Лазько Е.Е., Гладков Н.Г. Ультрабазиты и габброиды впадины Айпод (разлом Яп, Филиппинское море) // Известия АН СССР, серия геологическая. 1991. № 6. C. 47-65].

MacLeod C.J., Searle R.C., Murton B.J., Casey J.F., Mallows C., Unsworth S.C., Achenbach K.L., Harris M., 2009. Life cycle of oceanic core complexes. Earth and Planetary Science Letters 287 (3-4), 333-344. https://doi.org/10.1016/ j.epsl.2009.08.016.

Molnar P., Atwater T., 1978. Interarc spreading and Cordilleran tectonics as alternates related to the age of subducted oceanic lithosphere. Earth and Planetary Science Letters 41 (3), 330-340. https://doi.org/10.1016/0012-821X (78)90187-5.

Ohara Y., Fujioka K., Ishizuka O., Ishii T., 2002. Peridotites and volcanics from the Yap arc system: implications for tectonics of the southern Philippine Sea Plate. Chemical Geology 189 (1-2), 35-53. https://doi.org/10.1016/S00092541(02)00062-1.

Ohara Y., Yoshida T., Kato Y., Kasuga S., 2001. Giant megamullion in the Parece Vela backarc basin. Marine Geophysical Researches 22 (1), 47-61. https://doi.org/10.1023/A:1004818225642.

Pearce J., 2002. The oceanic lithosphere. JOIDES Journal 28 (1), 61-66 (Special Issue: Achievements and Opportunities of Scientific Ocean Drilling).

Philpotts A., Ague J., 2009. Principles of Igneous and Metamorphic Petrology. Cambridge University Press, Cambridge, 684 p. https://doi.org/10.1017/CB09780511813429.

Pushcharovsky Yu.M., Skolotnev S.G., Peive A.A., Bortnikov N.S., Bazilevskaya E.S., Mazarovich A.O., 2004. Geology and Metallogeny of the Mid-Atlantic Ridge: 5-7 N. GEOS, Moscow, 151 p. (in Russian) [Пущаровский Ю.М., Сколотнев С.Г., Пейве А.А., Бортников Н.С., Базилевская Е.С., Мазарович А.О. Геология и металлогения СрединноАтлантического хребта: 5-7 с.ш. М.: ГЕОС, 2004. 151 с.].

Queiroga G., Martins M., Kuznetsov N., Chemale F. Jr., Dussin I., Pedrosa-Soares A.C., Kulikova K., de Castro M.P., 2016. Timing of lower crust generation in The Voykar ophiolite massif, Polar Urals, Russia: U-Pb (LA-ICP-MS) data from plagiogranite zircons. Ofioliti 41 (2), 75-84. https://doi.org/10.4454/ofioliti.v41i2.443.

Quick J.E., Denlinger R.P., 1993. Ductile deformation and the origin of layered gabbro in ophiolites. Journal of Geophysical Research: Solid Earth 98 (B8), 14015-14027. https://doi.org/10.1029/93JB00698.

Rudnick R., 1990. Growing from below. Nature 347 (6295), 711-712. https://doi.org/10.1038/347711a0.

Savel'eva G.N., Bortnikov N.S., Peyve A.A., Skolotnev S.G., 2006. Ultramafic rocks from the Markov Deep in the rift valley of the Mid-Atlantic Ridge. Geochemistry International 44 (11), 1105-1120. https://doi.org/10.1134/S0016702 906110024.

Savelieva G.N., Batanova V.G., Berezhnaya N.A., Presnyakov S.L., Sobolev A.V., Skublov S.G., Belousov I.A., 2013. Polychronous formation of mantle complexes in ophiolites. Geotectonics 47 (3), 167-179. https://doi.org/10.1134/ S0016852113030060.

Savelieva G.N., Sobolev A.V., Batanova V.G., Suslov P.V., Brügmann G., 2008. Structure of melt flow channels in the mantle. Geotectonics 42 (6), 430-447. https://doi.org/10.1134/S0016852108060022.

Savelyeva G.N., 1987. Gabbro-Ultrabasic Complexes of the Ural Ophiolites and Their Analogues in the Modern Oceanic Crust. Nauka, Moscow, 246 p. (in Russian) [Савельева Г.Н. Габбро-ультрабазитовые комплексы офиолитов Урала и их аналоги в современной океанической коре. М.: Наука, 1987. 246 с.]. 
Schilling J.G., Hanan B.B., McCully B., Kingsley R.H., Fontignie D., 1994. Influence of the Sierra Leone mantle plume on the equatorial Mid-Atlantic Ridge: A Nd-Sr-Pb isotopic study. Journal of Geophysical Research: Solid Earth 99 (B6), 12005-12028. https://doi.org/10.1029/94JB00337.

Searle R., 2013. Mid-Oceanic Ridges. Cambridge University Press, Cambridge, 318 p.

Sharkov E.V., 2006. Formation of Stratified Intrusive Rocks and Associated Mineralization. Nauchny Mir, Moscow, 364 p. (in Russian) [Шарков Е.В. Формирование расслоенных интрузивов и связанного с ними оруденения. М.: Научный мир, 2006. 364 с.].

Sharkov E.V., 2012. Cyclic development of axial parts of slow-spreading ridges: evidence from Sierra Leone area, the Mid-Atlantic Ridge, 5-7N. In: E.V. Sharkov (Ed.), Tectonics, recent advances. InTech, Rijeka, p. 3-36.

Sharkov E.V., Abramov S.S., Simonov V.A., Krinov D.I., Skolotnev S.G., Bel'tenev V.E., Bortnikov N.S., 2007. Hydrothermal alteration and sulfide mineralization in gabbroids of the Markov Deep (Mid-Atlantic Ridge, $6^{\circ} \mathrm{N}$ ). Geology of Ore Deposits 49 (6), 467-486. https://doi.org/10.1134/S1075701507060037.

Sharkov E.V., Bortnikov N.S., Bogatikov O.A., Zinger T.F., Bel'tenev V.E., Chistyakov A.V., 2005. Third Layer of the Oceanic Crust in the Axial Part of the Mid-Atlantic Ridge (Sierra Leone MAR Segment, 6º N). Petrology 13 (6), 540-570.

Sharkov E.V., Chistyakov A.V., Laz'ko E.E., 2001. The structure of the layered complex of the voikar ophiolite association (polar urals) as an indicator of mantle processes beneath a back-arc sea. Geochemistry International 39 (9), 831-847.

Sharkov E.V., Shatagin K.N., Krassivskaya I.S., Chernyshev I.V., Bortnikov N.S., Chistyakov A.V., Trubkin N.V., Kramchaninov A.Y., 2008. Pillow lavas of the Sierra Leone test site, Mid-Atlantic Ridge, $5^{\circ}-7^{\circ} \mathrm{N}$ : Sr- $\mathrm{Nd}$ isotope systematics, geochemistry, and petrology. Petrology 16 (4), 335-352. https://doi.org/10.1134/S0869591108040024.

Sharkov E.V., Svalova V.B., 2011. Geological-geomechanical simulation of the Late Cenozoic geodynamics in the Alpine-Mediterranean Mobile Belt. In: E.V. Sharkov (Ed.), New Frontiers in Tectonic Research - General Problems, Sedimentary Basins and Island Arcs. InTech, Rijeka, p. 19-38.

Sharma M., Hofmann A.W., Wasserburg G.J., 1998. Melt generation beneath ocean ridges: Re-Os isotopic evidence from the Polar Ural ophiolite. Mineralogical Magazine 62A (V.M. Goldschmidt Conference Abstracts, Toulouse, 1998), 1375-1376.

Sharma M., Wasserburg G.J., Papanastassiou D.A., Quick J.E., Sharkov E.V., Laz'ko E.E., 1995. High ${ }^{143} \mathrm{Nd} /{ }^{144} \mathrm{Nd}$ in extremely depleted mantle rocks. Earth and Planetary Science Letters 135 (1-4), 101-114. https://doi.org/ 10.1016/0012-821X(95)00150-B.

Silantyev S.A., 1998. Origin conditions of the Mid-Atlantic Ridge plutonic complex at 13-17 N. Petrology 6 (4), 351-387.

Simonov V.A., Kolobov V.Yu., Peive A.A., 1999. Petrology and Geochemistry of Geodynamic Processes in the Central Atlantic. Publishing House of SB RAS, SRC UIGGM, Novosibirsk, 226 p. (in Russian) [Симонов В.А., Колобов В.Ю., Пейве А.А. Петрология и геохимия геодинамических процессов в Центральной Атлантике. Новосибирск: Изд-во СО РАН, НИЦ ОИГГМ, 1999. 226 с.].

Simonov V.A., Sharkov E.V., Kovyazin S.V., 2009. Petrogenesis of the Fe-Ti intrusive complexes in the Sierra Leone region, Central Atlantic. Petrology 17 (5), 488-502. https://doi.org/10.1134/S086959110905004X.

Skolotnev S.G., Bel'tenev V.E., Lepekhina E.N., Ipat'eva I.S., 2010. Younger and older zircons from rocks of the oceanic lithosphere in the Central Atlantic and their geotectonic implications. Geotectonics 44 (6), 462-492. https:// doi.org/10.1134/S0016852110060038.

Thy P., 2003. Igneous petrology of gabbros from Hole 1105A: oceanic magma chamber processes. In: J.F. Casey, D.J. Miller (Eds.), Hammer Drilling and NERO, Scientific Results. Proceedings of the Ocean Drilling Program, vol. 179, p. 1-76. https://doi.org/10.2973/odp.proc.sr.179.017.2003.

Tucholke B.E., 1998. Discovery of "Megamullions" Reveals Gateways Into the Ocean Crust and Upper Mantle. OCEANUS 41 (1), 15-19.

Turcotte D.L., Schubert G., 2002. Geodynamics. 2nd edition. Cambridge University Press, Cambridge, 456 p.

Vasco D.W., Johnson L.R., Pulliam R.J., Earle P.S., 1994. Robust inversion of IASP91 travel time residuals for mantle $\mathrm{P}$ and $\mathrm{S}$ velocity structure, earthquake mislocations, and station corrections. Journal of Geophysical Research: Solid Earth 99 (B7), 13727-13755. https://doi.org/10.1029/93JB02023.

Wager L.R., Brown G.M., 1968. Layered Igneous Rocks. Oliver \& Boyd, Edinburgh - London, 588 р. [Русский перевод: Уэйджер Л., Браун Г. Расслоенные изверженные породы. М.: Мир, 1970. 553 с.].

Wilson M., 1989. Igneous Petrogenesis, a Global Tectonic Approach. Unvin Hyman, London, 466 p.

Zorin Y.A., Sklyarov E.V., Belichenko V.G., Mazukabzov A.M., 2007. Evolution of island arcs and geodynamics of the Eastern Central Asian Foldbelt in the Neogea. Doklady Earth Sciences 412 (1), 39-42. https://doi.org/10.1134/ S1028334X07010096. 


\section{CВЕДЕНИЯ ОБ АВТOPE | INFORMATION ABOUT AUTHOR}

\section{Евгений Витальевич Шарков}

докт. геол.-мин. наук, профессор

Институт геологии рудных месторождений, петрографии,

минералогии и геохимии РАН

119017, Москва, Старомонетный пер., 35, Россия

e-mail: sharkov@igem.ru

(iD) https://orcid.org/0000-0001-7344-6810

\section{Evgeny V. Sharkov}

Doctor of Geology and Mineralogy, Professor

Institute of Geology of Ore Deposits, Petrography,

Mineralogy and Geochemistry of RAS

35 Staromonetnyi per., Moscow 109017, Russia 